\title{
Impacts of future agricultural change on ecosystem service indicators
}

\author{
Sam S. Rabin ${ }^{1}$, Peter Alexander ${ }^{2,3}$, Roslyn Henry ${ }^{2}$, Peter Anthoni ${ }^{1}$, Thomas A. M. Pugh ${ }^{4,5}$, \\ Mark Rounsevell ${ }^{1}$, and Almut Arneth ${ }^{1}$ \\ ${ }^{1}$ Institute of Meteorology and Climate Research/Atmospheric Environmental Research, \\ Karlsruhe Institute of Technology, Garmisch-Partenkirchen, Germany \\ ${ }^{2}$ School of Geosciences, University of Edinburgh, Edinburgh, UK \\ ${ }^{3}$ Global Academy of Agriculture and Food Security, The Royal (Dick) School of Veterinary Studies, \\ University of Edinburgh, Edinburgh, UK \\ ${ }^{4}$ School of Geography, Earth and Environmental Sciences, University of Birmingham, Birmingham, UK \\ ${ }^{5}$ Birmingham Institute of Forest Research, University of Birmingham, Birmingham, UK
}

Correspondence: Sam S. Rabin (sam.rabin@kit.edu)

Received: 1 August 2019 - Discussion started: 15 August 2019

Revised: 4 March 2020 - Accepted: 23 March 2020 - Published: 23 April 2020

\begin{abstract}
A future of increasing atmospheric carbon dioxide concentrations, changing climate, growing human populations, and shifting socioeconomic conditions means that the global agricultural system will need to adapt in order to feed the world. These changes will affect not only agricultural land but terrestrial ecosystems in general. Here, we use the coupled land use and vegetation model LandSyMM (Land System Modular Model) to quantify future land use change (LUC) and resulting impacts on ecosystem service indicators relating to carbon sequestration, runoff, biodiversity, and nitrogen pollution. We additionally hold certain variables, such as climate or land use, constant to assess the relative contribution of different drivers to the projected impacts. Some ecosystem services depend critically on land use and management: for example, carbon storage, the gain in which is more than 2.5 times higher in a low-LUC scenario (Shared Socioeconomic Pathway 4 and Representative Concentration Pathway 6.0; SSP4-60) than a high-LUC one with the same carbon dioxide and climate trajectory (SSP3-60). Other trends are mostly dominated by the direct effects of climate change and carbon dioxide increase. For example, in those two scenarios, extreme high monthly runoff increases across $54 \%$ and $53 \%$ of land, respectively, with a mean increase of $23 \%$ in both. Scenarios in which climate change mitigation is more difficult (SSPs 3 and 5) have the strongest impacts on ecosystem service indicators, such as a loss of 13\%-19\% of land in biodiversity hotspots and a $28 \%$ increase in nitrogen pollution. Evaluating a suite of ecosystem service indicators across scenarios enables the identification of tradeoffs and co-benefits associated with different climate change mitigation and adaptation strategies and socioeconomic developments.
\end{abstract}

\section{Introduction}

Exploring how the agricultural system might shift under different plausible future climate and socioeconomic changes is critically important for understanding how the future world - with a population increase by 2100 ranging from 1.5 billion to nearly 6 billion people (KC and Lutz, 2017) - will be fed. In addition, land-based mitigation - reducing deforestation, increasing sequestration in natural and agricultural lands, and expanding biofuel use - might be an important piece in the strategy to achieve warming targets laid out in the Paris Agreement (Rogelj et al., 2018; van Vuuren et al., 2018). The implications of resultant shifts in land use areas and management inputs go far beyond food security. Human society depends on a wide range of ecosystem services which broadly fall into three categories (IPBES, 2018a): regulating (e.g., greenhouse gas sequestration, flood control), mate- 
rial (e.g., food and feed production), and non-material (e.g., learning and inspiration). These have all historically been strongly affected by land use and management.

Declining biodiversity due to the loss and degradation of habitat (Jantz et al., 2015; Newbold et al., 2015) raises moral and ethical questions regarding extinction, represents a loss of a non-material ecosystem service per se, and indirectly harms other ecosystem services by impairing system function (Simpson et al., 1996; Tilman et al., 2014; IPBES, 2018b). The conversion of forests and other ecosystems to croplands or pasture has also, by releasing carbon from vegetation and soil pools, caused about a third of humanity's $\mathrm{CO}_{2}$ emissions since 1750 (Ciais et al., 2013). Land use change also alters how vegetation intercepts rainfall and takes up water from the soil, affecting the amount and timing of runoff and thus water supply and flood risk (Wheater and Evans, 2009; Haddeland et al., 2014). This affects both human and natural systems, as do changes in runoff quality: nitrogen (N) compounds from fertilizer dissolve in soil water and are transported from agricultural land to freshwater and marine ecosystems. There, this nitrogen pollution can cause eutrophication and affect various ecosystem services, including fishery production (Vitousek et al., 1997). Fertilizer also produces air pollution in the form of nitric oxides (which contribute to respiratory illnesses; Yang and Omaye, 2009) and the greenhouse gas nitrous oxide (the third-largest component of anthropogenic climate change; Fowler et al., 2009; Myhre et al., 2013; Shcherbak et al., 2014). Where nitrogen oxides are elevated, they can react with biogenic volatile organic compounds (BVOCs), which are emitted by plants - especially woody species (Rosenkranz et al., 2014) - for a variety of physiological functions. These reactions produce tropospheric ozone, which is harmful to human health (Ebi and McGregor, 2008), can negatively affect photosynthesis (Ashmore, 2005), and is a greenhouse gas (Myhre et al., 2013). BVOCs also have other, more complicated implications for regulating and material ecosystem services. They can warm the planet by increasing methane lifetime (Young et al., 2009), but on the other hand they help form tropospheric aerosols, which increase reflectance and boost photosynthesis via diffuse radiation (Rap et al., 2018; Sporre et al., 2019). The latter can improve crop yields, but BVOCenhanced ozone formation can work against that effect (Feng and Kobayashi, 2009).

As global environmental and societal changes continue over the coming decades, it is critical that we understand not just the impacts on the natural world, but how those impacts feed back onto humanity. To explore the possible future evolution of the Earth system and society, models have been developed that simulate the global economy, the natural world, and their interactions. A substantial body of research has been built up using such models to examine how future land use change will affect individual ecosystem services such as carbon sequestration (Brovkin et al., 2013; Lawrence et al., 2018), biodiversity (Jantz et al., 2015; Hof et al., 2018; Di Marco et al., 2019), and water availability and flood risk (Davie et al., 2013; Elliott et al., 2014; Asadieh and Krakauer, 2017). Much less work has been undertaken to evaluate the future of a suite of ecosystem services in an integrated way (Krause et al., 2017; Molotoks et al., 2018). However, such analyses provide critically important evidence for balancing the many competing demands on the land system while achieving climate and societal targets such as those laid out in the Paris Agreement and United Nations Sustainable Development Goals (Eitelberg et al., 2016; Benton et al., 2018; Verhagen et al., 2018).

Previously (Alexander et al., 2018), we used the Parsimonious Land Use Model (PLUM) to estimate future land use and management change, based on changing socioeconomic conditions as well as climate effects on agricultural yield provided by the Lund-Potsdam-Jena General Ecosystem Simulator (LPJ-GUESS) vegetation model. This coupled model system - the Land System Modular Model, or LandSyMM is among the state of the art in global land use change models due to the high level of detail that it considers in the response of agricultural yields to management inputs. Whereas most integrated assessment models rely on generic responses of yield to changing climate, atmospheric carbon dioxide, and fertilizer, LPJ-GUESS simulates these processes mechanistically. Land use optimization also happens at a finer grain in LandSyMM (about 3400 grid cell clusters) than in other similar model systems (tens to hundreds of clusters). Finally, LandSyMM is unique in that PLUM allows short-term overand undersupply of commodities relative to demand (rather than assuming market equilibrium in every year). Here, we take advantage of the mechanistic modeling of terrestrial ecosystems provided by LPJ-GUESS to explore how PLUMgenerated future land use and management trajectories - under different scenarios of future socioeconomic development and climate change - differ in their consequences for a range of regulating and material ecosystem services.

\section{Methods}

\subsection{LPJ-GUESS}

LPJ-GUESS is a dynamic global vegetation model that simulates - here, at a spatial resolution of $0.5^{\circ}$ - physiological, demographic, and disturbance processes for a variety of plant functional types (PFTs) on natural land (Smith et al., 2001; Smith et al., 2014). Hydrological and most physiological processes are modeled at daily temporal resolution; vegetation growth, establishment, disturbance (including land use change), and mortality happen annually. Agricultural land is also included, with cropland and pasture being restricted in the types of plants allowed and experiencing annual harvest. Transitions among land use types are given as an input, with LPJ-GUESS calculating the associated change in carbon pools and fluxes (Lindeskog et al., 2013). Four crop functional types (CFTs) are represented: $\mathrm{C}_{3}$ cereals sown 
in winter, $\mathrm{C}_{3}$ cereals sown in spring, $\mathrm{C}_{4}$ cereals, and rice (Olin et al., 2015a). Nitrogen limitation on plant growth is modeled, with cropland able to receive fertilizer applications (Smith et al., 2014; Olin et al., 2015b). The mechanistic representation of wild plant and crop growth accounts for the $\mathrm{CO}_{2}$ fertilization effect, by which productivity can be enhanced due to improved water use efficiency and (in $\mathrm{C}_{3}$ plants) reduced photorespiration (Smith et al., 2014). In an intercomparison of eight vegetation models over 19812000 (Ito et al., 2017), LPJ-GUESS simulated a mean global gross primary productivity very close to the ensemble average, although with the second-steepest increasing trend. LPJGUESS has also been shown to realistically simulate the effects of elevated $\mathrm{CO}_{2}$ on temperate cereal yield (Olin et al., $2015 \mathrm{~b}$ ), although the latter effect is stronger than in other crop models (Pugh et al., 2020). Changes to irrigation, water demand, water supply, and plant water stress as described in the Supplement of Alexander et al. (2018) were included. Most importantly, these changes include (a) increasing maximum irrigation to allow it to bring soil to moisture levels well above the wilting point, and (b) a factor reflecting how soil moisture extraction gets more difficult as the soil gets drier.

LPJ-GUESS simulates variables that can be used as indicators of a number of provisioning and regulating ecosystem services (see also Table 1 in Krause et al., 2017); these are described in Sect. 2.5.

\subsection{PLUM}

PLUM is designed to produce trajectories of land use and management based on socioeconomic trends and grid-celllevel crop and pasture productivity at a resolution of $0.5^{\circ}$ (Engström et al., 2016b; Alexander et al., 2018). Food demand is projected into the future based on external scenario projections of country-level population and gross domestic product (GDP), using the historical relationship of per capita GDP to consumption of each of six crop types $-\mathrm{C}_{3}$ cereals, $\mathrm{C}_{4}$ cereals, rice, oil crops, pulses, and starchy roots - plus ruminant and monogastric livestock (FAOSTAT, 2018a, b). Demand of a seventh crop type - dedicated bioenergy crops such as Miscanthus - is specified based on an exogenous scenario. PLUM calculates the demand for food crops both for human consumption and feed for monogastric livestock, plus any ruminants not raised on pasture.

Demand is satisfied at the country level by either domestic production or imports, the balance between which is determined considering commodity prices, management costs (fertilizer, irrigation, land conversion, and "other management" such as pesticide use), and changing LPJ-GUESSsimulated productivity due to climate change and $\mathrm{CO}_{2}$ under a range of irrigation-fertilization treatments. The latter are assumed to produce diminishing returns, such that increasing them increases yield at low intensity levels, but less and less so at higher levels, approaching a yield asymptote.
To solve for land use areas and inputs that satisfy demand, PLUM uses least-cost optimization, which allows for shortterm resource surpluses and deficits. Such imbalances can be significant in the real world: global supply of major cereal crops frequently swings $5 \%$ to $10 \%$ out of equilibrium on an annual aggregate basis, and more extreme imbalances can be seen at the scale of individual countries (FAOSTAT, 2018a). These dynamics are not captured by equilibrium models, such as those used in other land use and integrated assessment models, which represent for each year the stable state that the economic system would move to eventually if the environment did not change. Because global agricultural markets are not in equilibrium, disequilibrium models are needed to capture the real-world process of moving towards - but not reaching - equilibrium in a constantly changing economic and physical environment. Disequilibrium models have received varying amounts of attention in the literature over time (e.g., Kaldor, 1972; Mitra-Kahn, 2008; Arthur, 2010), and to our knowledge PLUM is the first land use model to incorporate one.

The composition of livestock feed (in terms of which crops are used) is assumed to be flexible, which can result in large interannual fluctuations in demand and production of individual crops as their prices change relative to one another. This is seen, for example, in Fig. S10 in the Supplement, where oil crop demand in the US and Canada triples from one year to the next. This assumption is not expected to materially affect the results in terms of gross decadal trends in total agricultural area and management inputs.

As outputs (feeding into LPJ-GUESS for use in LandSyMM), PLUM produces half-degree gridded maps of land use area (cropland, pasture, and non-agricultural land), crop distribution (fraction of cropland planted with each crop type), irrigation intensity, and nitrogen fertilizer application rate. Land use areas are calculated as net change, which neglects certain dynamics - such as shifting cultivation - that can have significant impacts on modeled carbon cycling especially in some regions (Bayer et al., 2017). Other ecosystem services could be affected as well. LandSyMM does not capture these dynamics, but this was considered an acceptable trade-off for computational efficiency.

\subsection{LandSyMM: combining LPJ-GUESS and PLUM}

This section and Fig. 1 provide an overview of how LPJGUESS and PLUM are combined in the LandSyMM runs presented in this work. More details on this coupling can be found in the Supplement.

The first step in running LandSyMM is to perform "yieldgenerating" runs in LPJ-GUESS. A simulation of the historical period generates a model state, which is needed so that vegetation and soil condition can be fed into subsequent runs (Fig. 1). From that state, we perform a series of runs that generate "potential yields" in every grid cell for each crop under six different management treatments in a factorial setup: fer- 


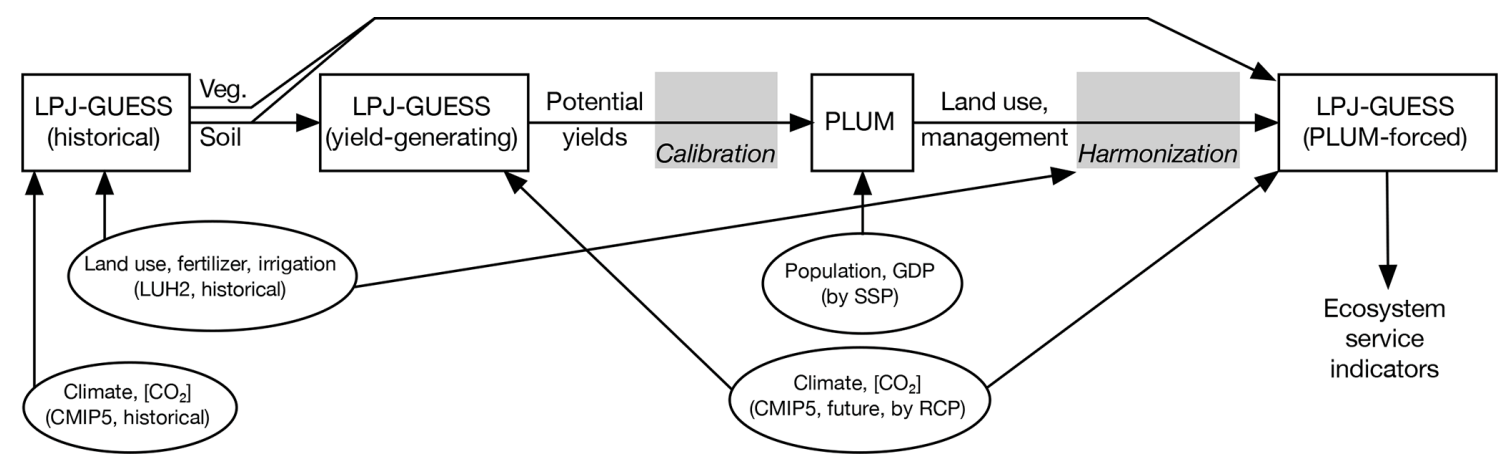

Figure 1. LandSyMM structural overview. Ovals represent external input data and white rectangles represent model runs, with arrows indicating data flow from one model run to the next. Gray rectangles represent model coupling processes whose external inputs have been excluded for simplicity; more information on these can be found in the Supplement.

tilization of 0,200 , and $1000 \mathrm{kgNha}^{-1}$, and either no irrigation or maximum irrigation. Changing pasture productivity is accounted for using annual average net primary productivity; for simplicity, we include pasture when using the phrase "potential yields". These potential yields account for changing productivity given changing climate and atmospheric $\mathrm{CO}_{2}$ concentration.

PLUM then combines the future potential yields from LPJGUESS (averaged over 5-year time steps) with its own estimates of future commodity demand to project land use areas, fertilizer application, and irrigation intensity (Fig. 1). PLUM has been found to perform well in this coupled system; its recreation of historical patterns and projections into the future are discussed in Alexander et al. (2018). Here, PLUM's demand estimates are driven by scenario-specific population and GDP data (Sect. 2.4).

The outputs of land use and management from PLUM for a given 2011-2100 scenario are fed into a final LPJ-GUESS run in order to produce projections of the ecosystem service indicators analyzed here (Fig. 1). However, the PLUM outputs must be processed first, because at the beginning of the future period they do not exactly match the land use and management forcings used at the end of the historical period. Feeding the raw PLUM outputs directly into LPJ-GUESS - causing large areas of sudden agricultural abandonment and expansion between 2010 and 2011 - would thus complicate interpretation of the results, especially of carbon cycling. We developed a harmonization routine, based on that published for Land Use Harmonization v1 dataset (LUH1) (Hurtt et al., 2011; http://luh.umd.edu/code.shtml, last access: 16 April 2020), that adjusts the PLUM outputs to ensure a smooth transition from the historical period to the future. While global totals are conserved in almost all cases, harmonization can produce notable differences at the regional scale. Details on this routine can be found in the Supplement (Sect. S3).

In addition to the LPJ-GUESS runs forced with harmonized PLUM-output land use and management trajectories, we perform several experiments to examine the impact of different factors on the land use and management projections generated by PLUM and thus the ecosystem service indicators simulated by LPJ-GUESS in the PLUM-forced runs. By holding either climate, atmospheric $\mathrm{CO}_{2}$, or land use and management constant (or for climate, looping through 30 years of temperature-detrended historical forcings) over 2011-2100, we can estimate the contribution of each to changing ecosystem service indicators in the future. Details regarding the inputs of these experimental runs can be found in Sect. 2.4 and the Supplement. The results of these experimental runs were used to inform interpretation of the results but are mostly not presented here. Instead, the Supplement contains figures supporting claims derived from the experimental runs, in addition to other figures that were not included here to conserve space. Runs are referred to using the naming convention described in Table 1. Note that all PLUM outputs consider LPJ-GUESS yields under changing climate and $\mathrm{CO}_{2}$ concentration, even when those outputs are fed into LPJ-GUESS runs with constant climate and/or $\mathrm{CO}_{2}$. Our analyses thus account only for the direct effects of changing climate and $\mathrm{CO}_{2}$ on ecosystem service indicators, rather than their indirect effects via land use and management.

\subsection{Input data and scenarios}

The experiments treated here are based around combined future climate-socioeconomic scenarios. Future population growth and economic development are derived from the Shared Socioeconomic Pathways (SSPs; O'Neill et al., 2014; IIASA, 2014). We use four of the five SSPs, which together cover a wide spectrum of possible storylines for the future evolution of the climate and society (O'Neill et al., 2014, 2017). SSP1 characterizes a world shifting to a more sustainable pathway, with low population growth and strong technological and economic developments. SSP3 describes a pathway with strong population growth and intensive resource usage, low technological development, and lessening globalization. SSP4 is a pathway of inequality with the potential 
Table 1. Naming convention for LandSyMM runs analyzed in this work, based on land use and management (LU, mgmt.), climate, and $\mathrm{CO}_{2}$ inputs. Bold indicates factors held constant in experimental runs. X refers to one of the SSPs $(1,3,4,5)$; YY refers to one of the RCPs (4.5, 6.0, 8.5). Unless otherwise specified, land use forcings are harmonized outputs from PLUM run fed with RCPY.Y-forced LPJ-GUESS potential yields and SSPX socioeconomic data and assumptions, and climate and $\mathrm{CO}_{2}$ forcings are from RCPY.Y.

\begin{tabular}{llll}
\hline Experiment name & LU, mgmt. & Climate & $\mathrm{CO}_{2}$ \\
\hline sXlum_rYYclico2 (all varying) & $2011-2100$ & $2011-2100$ & $2011-2100$ \\
rYYclico2 (constant LU/mgmt.) & $\mathbf{2 0 1 0}^{\mathrm{a}}$ & $2011-2100$ & $2011-2100$ \\
sXlum_rYYco2 (constant climate) & $2011-2100$ & $\mathbf{1 9 8 1 - 2 0 1 0}^{\mathrm{b}}$ & $2011-2100$ \\
sXlum_rYYcli (constant $\mathrm{CO}_{2}$ ) & $2011-2100$ & $2011-2100$ & $\mathbf{2 0 1 0}^{\mathrm{c}}$ \\
sXlum (constant climate and $\mathrm{CO}_{2}$ ) & $2011-2100$ & $\mathbf{1 9 8 1 - 2 0 1 0}^{\mathrm{b}}$ & $\mathbf{2 0 1 0}^{\mathrm{c}}$ \\
rYYco2 (constant LU/mgmt. and climate) & $\mathbf{2 0 1 0}^{\mathrm{a}}$ & $\mathbf{1 9 8 1 - 2 0 1 0}^{\mathrm{b}}$ & $\mathbf{2 0 1 1 - 2}^{\mathrm{a}}$ \\
rYYCli (constant LU/mgmt. and $\mathrm{CO}_{2}$ ) & $\mathbf{2 0 1 0}^{\mathrm{a}}$ & $2011-2100$ & $\mathbf{2 0 1 0}^{\mathrm{c}}$ \\
\hline
\end{tabular}

a From LUH2 (Hurtt et al., 2020) and Zhang et al. (2017). ${ }^{\mathrm{b}}$ Historical (not RCP) climate with temperature detrended. These 30 years are repeated throughout the future period: 2011 uses 1981 climate, 2012 uses 1982 climate, etc. ${ }^{\mathrm{c}}$ Approximately $389 \mathrm{ppm}$.

for competition over resources and resource intensification. SSP5 is a pathway dependent on fossil fuels with low population growth, strong globalization, and high economic and technological growth. (SSP2, a "middle-of-the-road" pathway intermediate between the other four SSPs, is not considered here.)

Scenarios of future climate change and atmospheric $\mathrm{CO}_{2}$ concentrations are based on the Representative Concentration Pathways (RCPs; van Vuuren et al., 2011). SSPs are paired with RCPs based on what sort of climate change could be expected under each SSP's storyline: SSP1 with RCP4.5, SSP3 and 4 with RCP6.0, and SSP5 with RCP8.5. RCP numbering refers to each scenario's average global radiative forcing $\left(\mathrm{W} \mathrm{m}^{-2}\right)$ in 2100 .

We use climate input data from the fifth Coupled Model Intercomparison Project (CMIP5; Taylor et al., 2012) outputs of the IPSL-CM5A-MR climate model (Dufresne et al., 2013). Maps of temperature and precipitation change over the simulation period for each RCP are presented in the Supplement (Fig. S4). The CMIP5 runs did include land use change but not the trajectories output by PLUM. As such, and as with all models that are not climate coupled but rather use offline forcings, we do not consider the effects of our simulated land use change on climate. We also use just one climate model, and as such the only uncertainty explored in this work is uncertainty related to scenario choice.

Future socioeconomic data - country-level population and GDP projections - are taken from version 0.93 of the SSP database (IIASA, 2014). Demand of dedicated bioenergy crops such as Miscanthus is specified according to the SSP2 scenario from the MESSAGE-GLOBIOM model described by Popp et al. (2017); demand for bioenergy from food crops is specified to double from 2010 by 2030 and thereafter remain constant. The SSP narratives also affected parameters within PLUM. These included input and transport costs, tariffs, and minimum non-agricultural area (which places an upper limit on the total fraction of a grid cell that PLUM can allocate to cropland and pasture). Values were estimated for each SSP based on an interpretation of the storylines (O'Neill et al., 2017; Engström et al., 2016a) and can be found in Table S6. Because of these scenario-specific parameters, the raw PLUM outputs are not necessarily expected to match at the beginning of the period.

Historical land use areas (cropland and pasture fractions), irrigation, and synthetic nitrogen fertilizer application levels were taken from the LUH2 dataset (Hurtt et al., 2020). Historical manure application rates (simplified upon import to LPJ-GUESS as pure nitrogen addition) come from Zhang et al. (2017). Historical crop distributions (i.e., given LUH2 cropland area in a grid cell, what fraction was rice, starchy roots, etc.) came from the MIRCA2000 dataset (Portmann et al., 2010) and were held constant throughout the historical period.

\subsection{Ecosystem service indicators}

LPJ-GUESS simulates a number of output variables that here serve as the basis for quantifying ecosystem services. The carbon sequestration performed by terrestrial ecosystems is measured as the simulated change in total carbon stored in the land system, including both vegetation and soil. Ecosystem nitrogen in LPJ-GUESS is lost in liquid form via leaching (a function of percolation rate and soil sand fraction), and in gaseous form through denitrification ( $1 \%$ of the soil mineral nitrogen pool per day) and fire. Here, we combine these into a value for total $\mathrm{N}$ loss. LPJ-GUESS also simulates the emission of isoprene and monoterpenes - the most prevalent BVOCs in the atmosphere (Kesselmeier and Staudt, 1999) - and accounts for three important factors regulating their emission: temperature, $\mathrm{CO}_{2}$ concentration $\left(\left[\mathrm{CO}_{2}\right]\right)$, and changing distribution of woody plant species due to climate and land use change (Arneth et al., 2007b; Schurgers et al., 2009; Hantson et al., 2017). 
LPJ-GUESS simulates basic hydrological processes such as evaporation, transpiration, and runoff. The latter is calculated as the amount of water by which soil is oversaturated after precipitation, leaf interception, plant uptake, and evaporation. We present change in average annual runoff as a general indicator of trend in water availability. After Asadieh and Krakauer (2017), we also use the difference between 19712000 and 2071-2100 in the 95th percentile of monthly surface runoff (P95 month) as a proxy for changing flood risk (although note that those authors used daily values), and the difference in the 5th annual percentile ( $\left.\mathrm{P} 5_{\text {year }}\right)$ for changing drought risk. Note that we are referring to hydrologic drought, which can be contrasted with, e.g., meteorological drought (a long time with little or no precipitation) or socioeconomic drought (water supply levels too low to satisfy human usage demand; Wilhite and Glantz, 1985). As Asadieh and Krakauer (2017) note, these metrics do not translate directly into impacts due to the mitigation capacity and nonlinear effectiveness of reservoirs, flood control mechanisms, and other infrastructure, as well as changes in demand and mean climate. However, changes in streamflow extremes have served as rough indicators of changing risk in a number of previous global-scale studies (e.g., Tang and Lettenmaier, 2012; Hirabayashi et al., 2013; Dankers et al., 2014; Koirala et al., 2014). While LPJ-GUESS does not model the physical flow of water within and between grid cells, the predecessor LPJ model has been shown to compare well to dedicated hydrological models when aggregated to basin scale (Gerten et al., 2004). As such, where discussing geographic patterns, we will refer to basin-level results only.

Finally, we assess how much land is converted to agriculture within the Conservation International (CI) hotspots, a set of 35 regions covering less than $3 \%$ of the Earth's land area but containing half the world's endemic plant species and over $40 \%$ of the world's endemic vertebrate animal species (Myers et al., 2000; Mittermeier et al., 2004). These regions each contain at least 1500 endemic vascular plant species and have already lost at least $70 \%$ of their original natural vegetation, thus representing highly diverse areas presently at high risk of habitat loss. Note that our chosen metric does not consider areas where agricultural abandonment could lead to a long-term increase in biodiversity, because it is impossible to determine where and how soon, given enough newly available land, there would be sufficient vascular plant richness to qualify as a biodiversity hotspot.

\section{Results and discussion}

\subsection{Land use areas and management inputs}

LandSyMM simulates net global loss of natural land area over the 21st century in all scenarios (Fig. 2), with SSP3 experiencing the greatest loss of area (10\%), SSP1 the least (3\%), and SSPs 4 and 5 an intermediate loss (6\%). These patterns are mostly reversed for pasture area change, in which all scenarios show an increase, although the trajectory for SSP5 is more similar to that of SSP3. PLUM also simulates net increased cropland area globally in all scenarios, with SSPs 1 and 5 showing the least increase, SSP4 more, and SSP3 the most.

Cropland expansion happens at a more or less constant rate in SSP3 and SSP4, but these scenarios experience very different trajectories of crop commodity demand: SSP4 approximately levels off around mid-century, whereas SSP3 experiences only a brief slowdown in growth followed by constantly increasing demand through 2100 (Fig. S5). The majority of the increased demand in the first half of the century is satisfied by fertilizer application, which increases by more than $75 \%$ from the 2010s to the 2050s while crop area increases by less than $15 \%$. However, management inputs per hectare in SSP3-60 approximately plateau after mid-century (Fig. S6), while crop demand rises $16 \%$. Cropland area expands about $10 \%$ between 2050 and 2100 , with boosted productivity - thanks to climate change and/or $\mathrm{CO}_{2}$ fertilization - helping to satisfy the rest of the increased demand. Since SSP4-60 experiences the same climate and $\mathrm{CO}_{2}$ fertilization but with level crop demand during the second half of the century, management inputs decrease after about 2050. PLUM prescribes lower irrigation rates by the end of the century for most scenarios (Figs. 2, S6). This is enabled by higher global mean rainfall in all RCP scenarios, as evidenced by the bars for runoff in Fig. 4, as well as by improved water use efficiency for crops other than $\mathrm{C}_{4}$ cereals due to increased $\mathrm{CO}_{2}$ concentrations. Crop demand increase in SSP3-60 outweighs these effects, however, resulting in higher irrigation in that scenario.

Although population growth in SSP5-85 is more than twice that of SSP1-45, PLUM simulates very similar trajectories of global crop demand in both: an increase until about 2040 followed by a decrease for the rest of the century, with SSP5-85 crop demand ending slightly higher. SSP5-85 livestock demand increases about $20 \%$ more than in SSP1-45, which explains the rest of the difference in global caloric needs between the two scenarios (Fig. S5). However, because SSP5-85 experiences much stronger climate change and $\mathrm{CO}_{2}$ increase, the two scenarios differ importantly in how they satisfy their crop demand over the century. Whereas cropland area increases more or less constantly in SSP1-45 (slightly slowing throughout), in SSP5-85 it decreases through about 2050, after which it increases slowly, ending at a slightly lower global extent than in SSP1-45 despite a jump in the early 2090s as feed becomes more important in raising ruminant livestock (Fig. S7). Crop production remains similar between the two scenarios, especially in the first half of the century, because SSP5-85 applies much more fertilizer and irrigation water per hectare (Fig. S6). This gap in these inputs narrows in the second half of the century as climate change and the $\mathrm{CO}_{2}$ fertilization effect become even stronger in SSP5-85 relative to SSP1-45, although the latter also be- 
Change in land use and drivers, 2001-2010 to 2091-2100

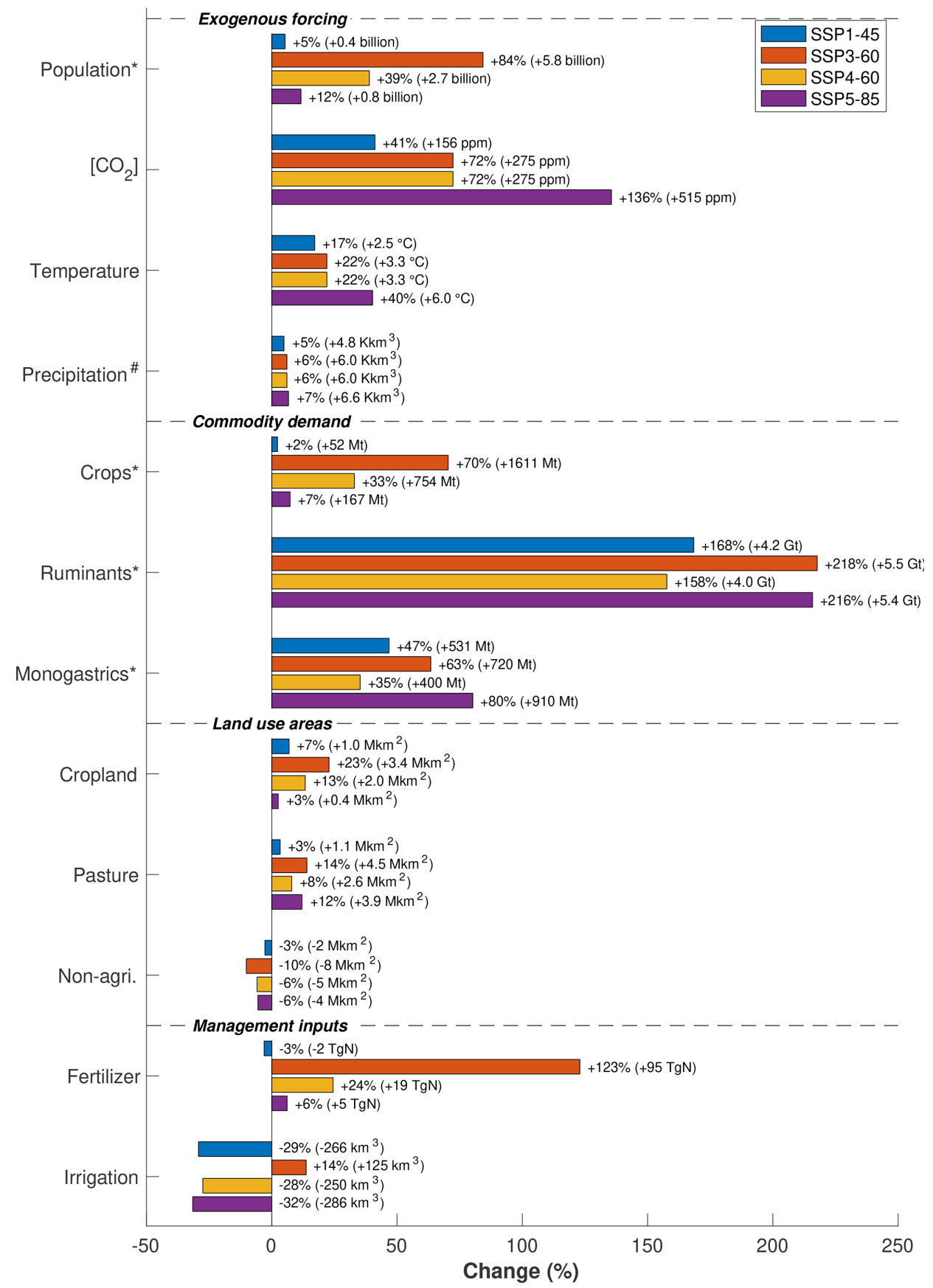

Figure 2. Percent change in global socioeconomic, land management, and atmospheric variables between 2001-2010 and 2091-2100. Ruminant demand given in units of feed-equivalent weight. * The variables whose baseline is 2010 instead of the average over 2001-2010. \# The time periods compared for precipitation were 1971-2000 and 2071-2100 due to high temporal variability.

gins to increase PLUM's “other management” intensity (representing, e.g., pesticide application).

Figure 3 presents the change in cropland and pasture area over 2010-2100 for each scenario after harmonization. It should be noted that the harmonization process, while preserving global changes in net area change for each land use type, produces more gross area change. Where relevant, in this section and in the rest of the results, we will point out where apparent strong regional effects of land use change result from changes that were not present pre-harmonization.

Several regional patterns in crop area change stand out in Fig. 3: 
$\Delta$ cropland area, 2010-2100
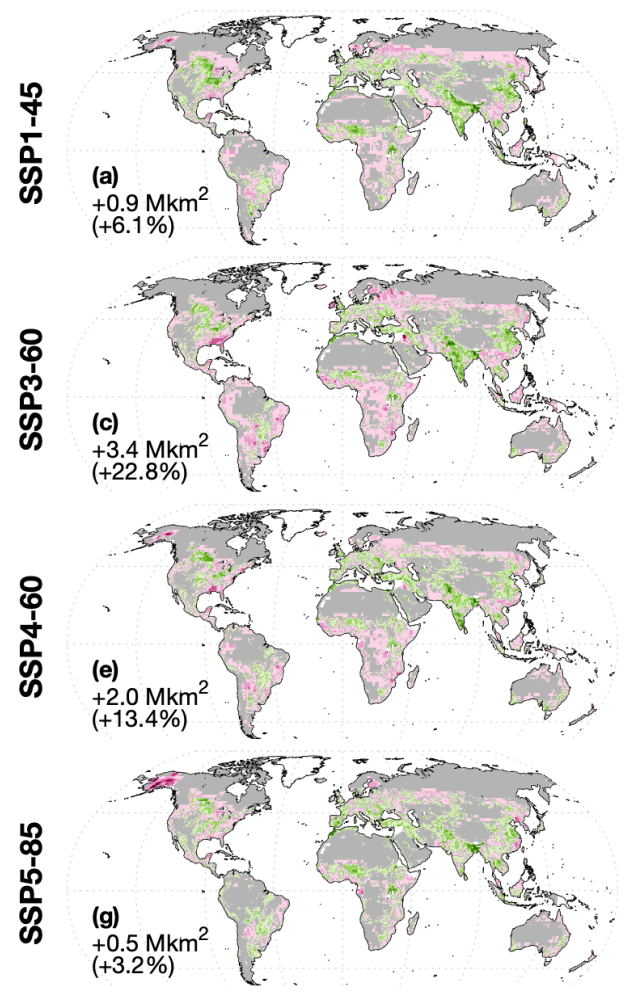

$\Delta$ pasture area, 2010-2100
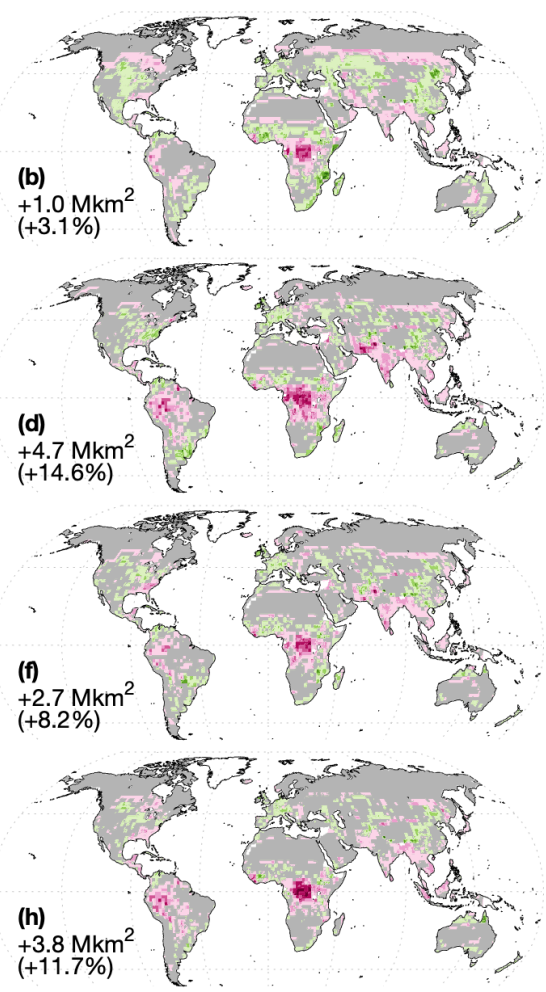

$\begin{array}{lllllllllllll}-100 & -80 & -60 & -40 & -20 & -3 & 3 & 20 & 40 & 60 & 80 & 100 & (\%)\end{array}$

Figure 3. (a, c, e, g) Change in cropland area (as fraction of grid cell) from 2010 (LUH2) to 2100 (harmonized PLUM) under each SSP-RCP scenario. (b, $\mathbf{d}, \mathbf{f}, \mathbf{h})$ As the left column but for pasture.

- North America loses cropland in parts of the Great Plains (mainly $\mathrm{C}_{3}$ cereals; Fig. S8) and the midwestern US (mainly oil crops; Fig. S9) in all scenarios after harmonization. However, this is exaggerated relative to the original PLUM outputs by approximately $1500 \%$, $1700 \%, 400 \%$, and $800 \%$ for SSPs 1, 3, 4, and 5, respectively. Similarly, harmonization inflates projected cropland expansion in the temperate forests of the eastern US and Canada: by approximately $800 \%$ for SSP145 and $100 \%$ for the other scenarios. On the other hand, large-scale cropland expansion in Alaska in all scenarios except SSP3-60 was almost entirely present in the raw PLUM outputs. This new cropland is entirely planted with spring wheat (Fig. S8) and is most extensive in SSP5-85, which shows the largest increase in North American cereal demand - nearly $250 \%$ by the end of the century (Fig. S10) - but also the largest potential yield increase in Alaska, thanks to high warming and $\mathrm{CO}_{2}$ fertilization. Indeed, by the end of the century, the potential yield of rainfed $\mathrm{C}_{3}$ cereals there is similar to or exceeds that of the parts of the Great Plains where cropland is lost (Fig. S11). It should be noted that while LPJ-GUESS includes several limitations on plant and soil processes based on air and soil temperature, the version used here does not represent permafrost dynamics, and so may be optimistic with regard to the increase in arable land area. However, permafrost extent is expected to decrease across parts of Alaska and the boreal zone as a whole, especially in high-temperatureincrease scenarios such as RCP8.5 (Lawrence et al., 2012; Pastick et al., 2015).

- Although crop demand in South Asia (here, India, Sri Lanka, Pakistan, Afghanistan, Bangladesh, Nepal, and Bhutan) increases by more than $100 \%$ in SSP5-85 and $170 \%$ in SSP3-60 (Fig. S12), after harmonization the cropland area in that region is greatly reduced: approximately $30 \%$ and $20 \%$, respectively. The raw PLUM outputs showed less loss (8\% and $10 \%$, respectively) but the same general pattern. Even so, PLUM projects that the region's crop production would approximately double in both scenarios to satisfy most of the increased demand (Fig. S12). While some of this is accomplished through increased management inputs in a region where the yield gap is large in the baseline, it also depends markedly on yield boosts due to in- 
creased rainfall (Fig. S4) and rising $\mathrm{CO}_{2}$ concentrations: $\mathrm{C}_{3}$ cereal yields in the constant land use experiments (rYYClico2) triple (RCP6.0) or quadruple (RCP8.5) across large parts of Pakistan and India. This is mostly due to a $\mathrm{CO}_{2}$ fertilization effect, especially in RCP8.5, which shows widespread areas of yield decline when only varying climate ( $185 \mathrm{cli}$, Fig. S13).

- PLUM expects sub-Saharan Africa to experience crop production increases even larger than South Asia, ranging from $+200 \%$ in SSP1-45 to $+500 \%$ in SSP3-60 (Fig. S14). In contrast to South Asia, nearly the entire region experiences negative yield effects from the changing climate, and the counteracting effect of $\mathrm{CO}_{2}$ fertilization results in yields that are only net slightly

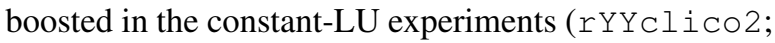
Fig. S13). The heightened production comes instead from increased management inputs and, to a much smaller degree, cropland expansion.

- China's crop demand peaks by about 2040; by the end of the century, it has either returned to (SSP360) or dropped past 2010 levels (by 30\%, 40\%, and $25 \%$ for SSP1-45, SSP4-60, and SSP5-85, respectively; Fig. S15). Crop imports decrease from $14 \%$ of demand to less than $6 \%$. This fits well with apparent net losses of cropland area in all scenarios, but note that harmonization switched SSP1-45's projection from an $8.5 \%$ gain to a $15 \%$ loss. Moreover, whereas PLUM projected cropland abandonment to occur in the montane shrublands and steppe of the Tibetan Plateau, after harmonization it occurs throughout the eastern temperate and subtropical forests. Slight cropland expansion projected by PLUM in China's subtropical moist forests is increased $300 \%-600 \%$ by harmonization in all scenarios except SSP1-45 (+21\%).

Pasture area is projected to expand significantly in the western Amazon in all scenarios (although in SSP1-45 this is strongly exaggerated by harmonization) and even more so in all scenarios in the African rainforest (Fig. 3). This tropical deforestation is largely driven by the increasing consumption of ruminant products in those regions: as incomes increase in developing tropical countries, PLUM projects greater consumption of commodities such as meat and milk and a reduction in staples such as starchy roots and pulses (Keyzer et al., 2005; Tilman et al., 2011). Depending on the SSP, ruminant products are simulated to account for $23 \%-43 \%$ of calories in central Africa by 2100 , compared to only $4 \%-7 \%$ of calories consumed in 2010 (caloric density derived from FAOSTAT, 2018c). Between $50 \%$ and $98 \%$ of the ruminant production increase in central Africa goes to this domestic consumption, with the rest being exported.

The African pasture expansion even occurs in SSP1-45, the "sustainability" scenario (O'Neill et al., 2017), in which LandSyMM simulates a net global pasture expansion of about $1 \mathrm{Mkm}^{2}$. For comparison, five other land use models all projected SSP1 pasture area decrease: by an average of about $3.4 \mathrm{Mkm}^{2}$ (Popp et al., 2017). While we do not expect LandSyMM's results to necessarily match those of other models, such a large, qualitative difference requires explanation. Several factors related to experimental setup and overall model structure likely contribute.

First, PLUM makes no assumption about changes in food production needs besides what occurs due to population and GDP changes. The storyline for SSP1, however, with its "low challenges to mitigation", suggests that people will gradually shift to lower-meat diets (O'Neill et al., 2017) than would be expected given GDP levels, at first at least in high-income countries. The Integrated Model to Assess the Global Environment (IMAGE) - which simulates a decrease in pasture area of about $7 \mathrm{Mkm}^{2}$ by the end of the century (Doelman et al., 2018) - incorporates this dietary shift as a $30 \%$ (global) reduction in meat consumption relative to what would have otherwise been simulated, and additionally includes a $33 \%$ reduction in food supply chain losses to represent efficiencies from improved management and infrastructure (Doelman et al., 2018). Weindl et al. (2017) use the Model of Agricultural Production and its Impact on the Environment (MAgPIE) to show that, under a scenario like ours where historical differences in livestock production efficiency are maintained or exacerbated, a shift to lower-meat diets can reduce the expansion of pasture in sub-Saharan Africa by over $50 \%$.

Second, the land use modeling components of most integrated assessment models (IAMs) - for example, all those contributing to the LUH2 trajectories (Hurtt et al., 2011) include demand for timber and other products. The carbon value of forests (and land more generally) can also be included by some, even if forest products are not explicitly modeled (e.g., MAgPIE; Humpenöder et al., 2014), which could come into play in scenarios with policy-based incentives designed to minimize emissions from deforestation and degradation and/or to maximize carbon sequestration. In contrast, PLUM includes neither forest products nor land carbon value. The only cost PLUM considers in converting a forest to agriculture is the cost of conversion, with the opportunity cost of lost forest products or services ignored. Similarly, the only incentive to replace existing agricultural land with forest would be to avoid costs associated with production. Including forest products, payments for carbon sequestration, and managed forestry into LandSyMM could result in more forest simulated over the course of the century. This is especially likely for SSP1, whose storyline specifies a gradual improvement in how the global commons are managed (O'Neill et al., 2017). As an example, IMAGE represented this improvement in SSP1-45 by (a) disallowing clearing of forests with carbon density greater than $200 \mathrm{tha}^{-1}$ and (b) reforesting half of the world's degraded or former forest.

The spread in land use area projections between the most extreme scenarios is much higher in this work than in 
Alexander et al. (2018), by around $500 \%$ for cropland and $700 \%$ for pasture. The primary reason for this increase in inter-scenario variation is that Alexander et al. (2018) used the SSP2 socioeconomic scenario for all RCPs, whereas here we compare different SSPs paired with appropriate RCPs. The wide variation among the SSPs in population and economic growth trajectories, along with SSP-specific PLUM parameters (Sect. 2.4), contributes to this increased spread. Even so, the LandSyMM trajectories are more closely clustered than those from some other land use models. IMAGE, for example, projects a range of cropland area increase from 0.4 to $5.3 \mathrm{Mkm}^{2}$ across the five SSPs, and pasture trajectories ranging from a decrease of $7.3 \mathrm{Mkm}^{2}$ to an increase of $4.4 \mathrm{Mkm}^{2}$ (Doelman et al., 2018). As described above, IMAGE makes a number of assumptions (based on the SSP storylines) that PLUM does not regarding future deviations from historical "business-as-usual" trends and relationships, including dietary shifts, reductions in food losses during transport, and forest conservation.

\subsection{Ecosystem service indicators}

\subsubsection{Carbon storage}

Carbon stored in the land system increases for all SSP-RCP scenarios, primarily due to an increase in vegetation carbon (Fig. 4). The increase in each scenario relative to the others depends on both intensity of climate change as well as amount of natural land lost. The large increase of atmospheric $\mathrm{CO}_{2}$ (and thus greater carbon fertilization) in RCP8.5 compared to RCP6.0 means that SSP5-85 has a much greater increase in terrestrial carbon storage than SSP4-60, despite those scenarios having similar trajectories of natural land area (Fig. 2). SSP3-60, which had the most natural land lost but only intermediate carbon fertilization, experiences the lowest increase in terrestrial C storage over the century - less than a third that of SSP4-60, which has the same trajectory of changing climate and atmospheric $\mathrm{CO}_{2}$ concentration but a much smaller population increase.

The contrast between effects of changing climate and atmospheric $\mathrm{CO}_{2}$ concentration vs. changing land use and management is starker for vegetation carbon than any other indicator variable examined here. In the constant-LU experiments ( $\mathrm{YYClicO} 2$ ), vegetation carbon increased $35 \%$, $43 \%, 43 \%$, and $54 \%$ for SSP1-45, SSP3-60, SSP4-60, and SSP5-85, respectively. The experiments with constant climate and $\mathrm{CO}_{2}$ (sXlum), on the other hand, showed respective decreases of $5 \%, 15 \%, 8 \%$, and $9 \%$.

Vegetation carbon increases are most pronounced in the tropical and boreal forests (Fig. 5) and are due primarily to $\mathrm{CO}_{2}$ fertilization, although increasing temperatures and growing season length also contribute in the boreal zone (Fig. S16). Extensive conversion to pasture far outweighs any carbon fertilization effect in the African tropical forest, which loses nearly all of its vegetation carbon and up to half its total carbon by 2100 in all scenarios.

Our results for carbon sequestration fall near the lower end of previously reported projections. Brovkin et al. (2013) examined the change in land carbon storage over 2006-2100 for a number of climate and land surface models. This included IPSL-CM5A-LR: the same IPSL-CM5A Earth system model that produced our forcings, except run at a lower resolution (hence, -LR instead of our -MR). They found that IPSL-CM5A-LR, when forced with emissions and land use change from RCP8.5, simulated uptake of $\sim 400 \mathrm{GtC}$. This is much greater than our finding of $\sim 89 \mathrm{GtC}$ under SSP585 (Fig. 4) despite their land use change scenario (from LUH1; Hurtt et al., 2011) having lost about $30 \%$ more nonagricultural land. A rough estimate (not shown) shows that running LPJ-GUESS under RCP8.5 with the same land use change as Brovkin et al. (2013) would have increased total carbon gain by $10 \%-15 \%$ at most. Instead, most of the difference is likely because none of the models in Brovkin et al. (2013) limit photosynthesis based on nitrogen availability.

Another study with LPJ-GUESS, Krause et al. (2017), used land use trajectories from the IMAGE and MAgPIE IAMs given RCP2.6 and SSP2, finding an increase in total land carbon pools of 34 and $64 \mathrm{GtC}$, respectively. Land use scenario played an important role in those results and likely contributes to the discrepancy with ours: their IMAGE pasture area increased from $\sim 35$ to $\sim 40 \mathrm{Mkm}^{2}$, whereas their MAgPIE pasture area decreased to $\sim 30 \mathrm{Mkm}^{2}$ and our SSP1-45 pasture stays around $\sim 32 \mathrm{Mkm}^{2}$. The IMAGE cropland area used in the baseline run of Krause et al. (2017) stayed approximately constant at $\sim 18 \mathrm{Mkm}^{2}$, as does our SSP1-45's (although at $\sim 15 \mathrm{Mkm}^{2}$ ), but their MAgPIE cropland area increased to $\sim 20 \mathrm{Mkm}^{2}$. Other important differences between the runs in Krause et al. (2017) and ours include our use of different climate forcings and a different photosynthetic scaling parameter (which accounts for realworld reductions in light use efficiency; Haxeltine and Prentice, 1996).

Krause et al. (2017) used climate forcings from the IPSLCM5A-LR model, which differs from what we used (IPSLCM5A-MR) only in that the former was run at a lower resolution. Both have similar mean global land temperature changes: for RCP8.5, on the low side of the high end of 18 CMIP5 models examined in Ahlström et al. (2012). This temperature change is strongly correlated with net ecosystem carbon exchange (land-to-atmosphere $\mathrm{C}$ flux, excluding fire emissions), so a different choice of climate forcings could have resulted in a stronger $\mathrm{C}$ sink or even a $\mathrm{C}$ source (Fig. S3 in Ahlström et al., 2012).

\subsubsection{Runoff}

Global precipitation increases in all scenarios (Fig. 2). Again, SSP3 and SSP4 (the two RCP6.0 scenarios) show similar changes; SSP1-45 shows a smaller increase, and SSP5-85 


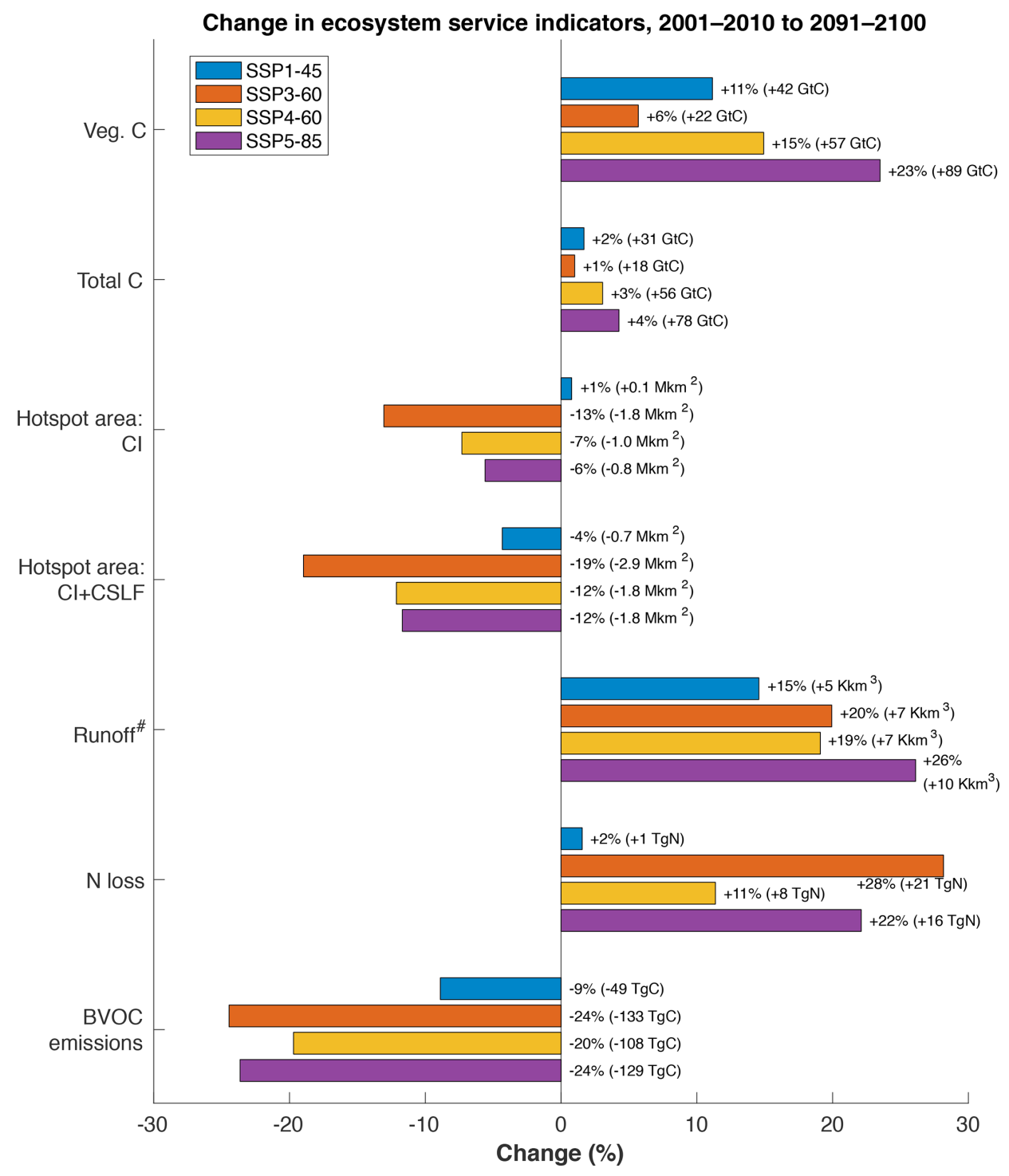

Figure 4. Percent global change in ecosystem service indicators between 2001-2010 and 2091-2100. CSLF: Congolian swamp and lowland forests (see Sect. 3.2.5). " The time periods compared for runoff were 1971-2000 and 2071-2100 due to high temporal variability.

shows the greatest. This pattern is roughly equivalent for changes in global runoff (Fig. 4); comparison of the experimental runs shows that climate change is the most important factor in increasing runoff at a global level in all scenarios (e.g., Fig. S17). While the impacts of increasing $\mathrm{CO}_{2}$ levels on runoff can be strongly regionally dependent (Zhu et al., 2012), we see that overall more $\mathrm{CO}_{2}$ means less runoff at a global level. A similar result was seen in two global vegetation models analyzed by Davie et al. (2013), although two others in that comparison showed the opposite effect. Land use change makes the least difference in terms of global annual runoff but can be important at the regional level. Deforestation in central Africa, for example, is the primary driver of increasing mean annual runoff there because of reduced evapotranspiration relative to existing vegetation. Note, how- ever, that LandSyMM can only represent the effect of land cover change on evapotranspiration and runoff directly - to include the impact of these flux differences on rainfall would require a coupling with a climate model.

Such regional patterns in runoff change are arguably more important than global means, since impacts of low water and flooding are actually felt at the level of individual river basins. To evaluate regional impacts, we calculated how much land area was subjected to intensified wet and/or dry extremes (Sect. 2.5). As discussed in Sect. 2.5, these values should not be taken as direct measurements of flooding or drought impacts, but they do serve as useful indicators.

Between 1971-2000 and 2071-2100 under SSP5-85, basins comprising $48 \%$ of land area showed increasing flood risk, with a mean P95 month increase of $32 \%$ (Table 2). Basin- 


\section{Diff. in vegetation C, 2000s to 2090s}

(a) SSP1-45

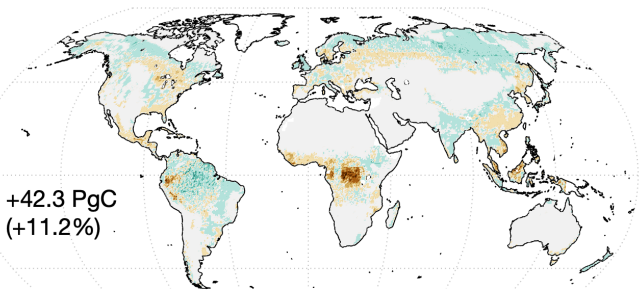

(b)

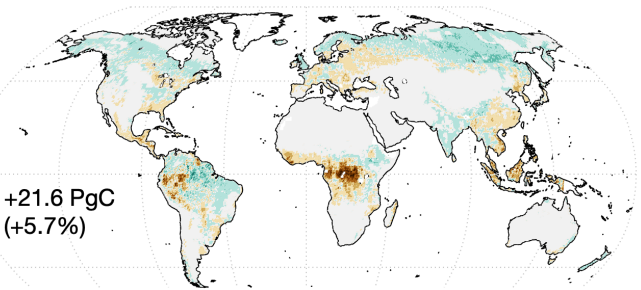

(c)

SSP4-60

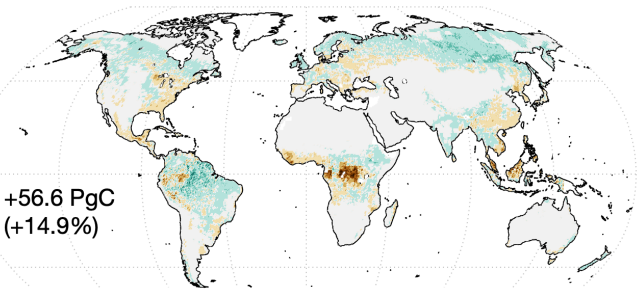

(d)

SSP5-85

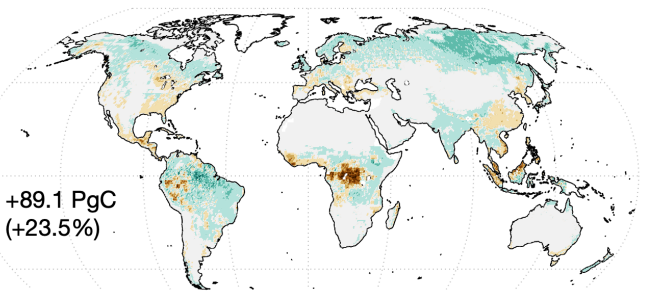

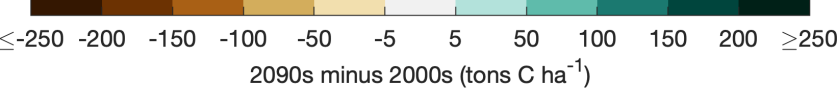

Figure 5. Maps showing difference in mean vegetation carbon between 2001-2010 ("2000s") and 2091-2100 ("2090s") for (a) SSP1-45, (b) SSP3-60, (c) SSP4-60, and (d) SSP5-85.

aggregated drought risk increased in $37 \%$ of land area, which experienced a mean $\mathrm{P} 5$ year decrease of $58 \%$. At the same time, however, $43 \%$ of land area showed decreasing flood risk (mean P95 month decrease $42 \%$ ), and $54 \%$ showed decreasing drought risk (mean $\mathrm{P} 5$ year increase $49 \%$ ). Other scenarios experienced similar fractions of area affected but smaller mean magnitude of change in flood or drought metric.

Most of the changes in SSP5-85 result from climate change, with some notable exceptions. Land use change
Table 2. Fraction of land with changing drought and/or flood risk between the last three decades of the 20th and 21st centuries in SSP5-85. Numbers in parentheses give each group's mean percent change in runoff. LandSyMM results have been aggregated to basin scale. AK2017: Asadieh and Krakauer (2017).

\begin{tabular}{lll}
\hline Class & LandSyMM & AK2017 \\
\hline$\uparrow$ drought risk ( $\downarrow$ P5) & $37 \%(-58 \%)$ & $43 \%(-51 \%)$ \\
$\downarrow$ drought risk ( $\uparrow$ P5) & $54 \%(+49 \%)$ & $33 \%(+30 \%)$ \\
$\uparrow$ flood risk ( $\uparrow$ P95) & $48 \%(+32 \%)$ & $37 \%(+25 \%)$ \\
$\downarrow$ flood risk ( $\downarrow$ P95) & $43 \%(-42 \%)$ & $40 \%(-21 \%)$ \\
\hline
\end{tabular}

alone contributes notably to increasing drought risk in eastern China, Pakistan, and northwest India (Fig. 6a), although the cropland abandonment driving most of these changes is more densely concentrated pre-harmonization. Agricultural expansion in Alaska and central Africa increases flood risk, while cropland abandonment in southern Pakistan decreases it (Fig. 6b). Similar effects in other regions in Fig. 6 - for example, increasing drought risk in Iraq and the central US, and increasing flood risk in northeast China - are driven by land use changes induced mostly by harmonization. (These land use changes would of course be happening somewhere and thus could still affect runoff similarly but in a different and potentially more concentrated region.) Land use change can also serve to counteract the impacts of climate change on runoff. For example, the severity of very low runoff events increases in central America, but it would have increased more if not for the expansion of agriculture there. The effects of land use change on runoff might be stronger and more widespread if LPJ-GUESS were run coupled with a climate model, which would account for associated changes in landatmosphere water and energy fluxes that can have similar impacts on the hydrological cycle as greenhouse gas emissions (Quesada et al., 2017).

Our results for SSP5-85 are compared with the RCP8.5 ensemble from Asadieh and Krakauer (2017) in Table 2. In all categories, LandSyMM finds a mean effect of stronger magnitude. LandSyMM finds less land in basins with increasing drought risk and more with decreasing drought risk than the Asadieh and Krakauer (2017) ensemble. Our results for fraction of land in basins with increasing or decreasing flood risk are more similar (within six percentage points) to those from the Asadieh and Krakauer (2017) ensemble. We expect that our results for land area with increasing and decreasing flood risk would have been lower and higher, respectively, had we used daily values for P95 as Asadieh and Krakauer (2017) did, instead of the LPJ-GUESS-output monthly values. We also expect that the average magnitude of change in those areas would have been closer to zero.

Another important difference between Asadieh and Krakauer (2017) and our analysis is that, whereas that study used five climate models, we used only one. Specifically, compared to 18 other models examined in Ahlström et al. 

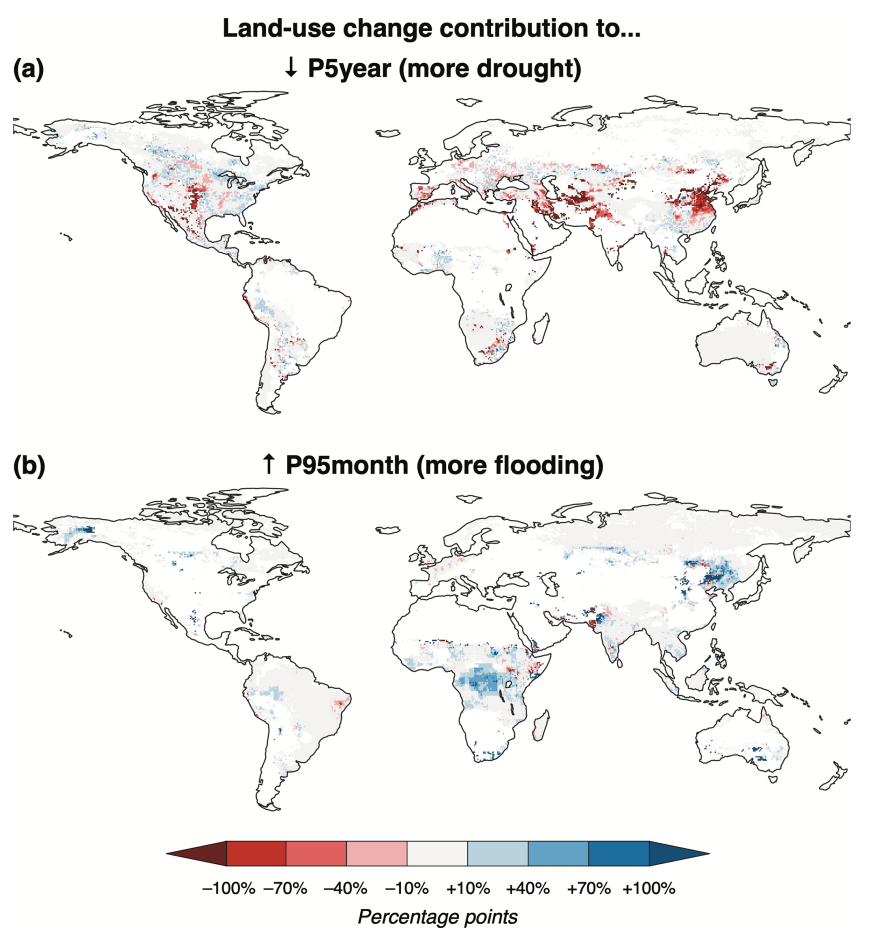

Figure 6. Contribution of land use change in SSP5-85 to (a) decreasing P5year (drought) and (b) increasing P95 month (flooding) between 1971-2000 and 2071-2100. White areas either did not have decreasing P5year or increasing P95 month, respectively, or were excluded due to low baseline runoff (after Asadieh and Krakauer, 2017). The contribution is calculated as the difference between the full run and constant-LU run (i.e., sXlum_rYYClico2 - rYYclico2).

(2012, their Fig. S2), IPSL-CM5A-MR in RCP8.5 simulates a much larger precipitation increase around the Equator, where we see the largest increase in runoff (Fig. S17a). Finally, LPJ-GUESS is not a full hydrological model: e.g., it does not include river routing. Land surface and hydrological models that include river routing, such as those included in the Asadieh and Krakauer (2017) ensemble, are needed to fully explore how changing precipitation, transpiration, and evaporation actually translate into changes in streamflow and surface water levels.

\subsubsection{Nitrogen losses}

While the evolution of total global nitrogen loss is fairly similar for all scenarios over the first two decades of the simulation, there are notable differences by the end of the century. SSP3-60 and SSP5-85 show large increases in N loss of $28 \%$ and $22 \%$, respectively. $\mathrm{N}$ loss increases about half as much in SSP4-60 (11\%) and only slightly in SSP1-45 (2\%).

Our $\mathrm{N}$ loss at the end of the historical period was similar to that of Krause et al. (2017), but whereas their runs estimated an increase in $\mathrm{N}$ losses of $60 \%-80 \%$ under RCP2.6, ours under SSP1-45 increased only $2 \%$. Krause et al. (2017) used fertilizer information from IMAGE and MAgPIE. Strong increases in fertilizer in those models resulted in strongly increased yields, but nitrogen limitation is alleviated at much lower levels in LPJ-GUESS. IMAGE and MAgPIE fertilization rates thus often exceeded what plants in LPJ-GUESS could actually take up, resulting in high amounts of $\mathrm{N}$ loss. Coupling LPJ-GUESS with PLUM provides for a more internally consistent estimate of future $\mathrm{N}$ losses, while still reproducing historical fertilizer application well (Alexander et al., 2018).

One interesting pattern is that climate and management changes can have similar effects on N losses. SSP3-60 has global fertilizer application more than double by the end of the century, while SSP5-85 fertilizer application at end of the run is slightly lower than in 2011 (Fig. 2). This is reflected in the $\mathrm{N}$ losses for the sXI um experiments, which increase $25 \%$ by the 2090s with SSP3 but only $7 \%$ with SSP5. However, in the full runs (sXlum_rYYclico2), SSP360 's $\mathrm{N}$ losses increase only about $27 \%$ more than SSP5-85's (Fig. 4). This is because the latter experiences higher average global temperatures (increasing gaseous losses) and a greater increase in runoff (increasing dissolved losses), due to the extreme RCP8.5 climate change scenario; in the constantLU (rYYClico2) experiments, $\mathrm{N}$ losses with RCP6.0 and RCP8.5 increase by $15 \%$ and $24 \%$, respectively. In either case - but especially under SSP3-60 - these increases in fertilizer usage and concomitant nitrogen pollution would exacerbate humanity's already unsustainable impacts on nutrient cycling (Rockström et al., 2009).

\subsubsection{BVOCs}

Global combined BVOC emissions over 2001-2010 totaled $\sim 546 \mathrm{TgC} \mathrm{yr}^{-1}\left(\sim 503\right.$ and $\sim 43 \mathrm{TgC} \mathrm{yr}^{-1}$ for isoprene and monoterpenes, respectively), which compares well with estimates from LPJ-GUESS using different land use scenarios (Arneth et al., 2008; Hantson et al., 2017; Szogs et al., 2017) and the Model of Emissions of Gases and Aerosols from Nature (MEGAN) model (Sindelarova et al., 2014). Emissions decline in all scenarios: by the most in SSP3-60 and SSP5-85, slightly less in SSP4-60, and the least in SSP1-45 (Fig. 4). This reflects a combination of the effects of land use change and $\left[\mathrm{CO}_{2}\right]$ increases. In the sXlum experiments, declines in combined BVOC emissions closely reflect declines in non-agricultural land area (most decrease with SSP3, less with SSP4 and SSP5, and least with SSP1; Fig. S18). This is a function of the much higher BVOC emissions potential of forests relative to cropland and pasture, as also seen in results from Hantson et al. (2017) and Szogs et al. (2017). In the full runs (sXlum_rYYclico2), BVOC emissions decline more in SSP5-85 than in SSP4-60 because the former has higher atmospheric $\left[\mathrm{CO}_{2}\right]$, which suppresses BVOC formation (Arneth et al., 2007a). The exact cellular regulatory processes of this " $\left[\mathrm{CO}_{2}\right]$ inhibition" remain enigmatic; recent 
evidence suggests that reduced supply of photosynthetic energy and reductants plays a major role (Rasulov et al., 2016).

Decreases in isoprene emissions are primarily driven by tropical deforestation for agriculture, especially the expansion of pasture in central Africa and South America, and to a lesser extent by the expansion of cropland in the southeastern US (Fig. S19), although the latter is exaggerated by harmonization. The suppressive effect of increasing $\left[\mathrm{CO}_{2}\right]$ is mostly counteracted in all RCPs by rising temperatures, which increase BVOC volatility. Monoterpene emissions in what is now tundra increase as woody vegetation expands there, but present-day boreal forests are the main areas of declining monoterpene emissions (Fig. S20). This is primarily due to the BVOC-suppressing effect of increasing $\left[\mathrm{CO}_{2}\right]$, but land use change also contributes, especially in Alaska.

It is important to keep in mind that the implications of changing BVOC emissions depend on complex, regionally varying atmospheric chemistry that governs their effects on existing species (e.g., methane) and the formation of secondary products (e.g., ozone and aerosols). The LandSyMM framework, lacking as it does an atmospheric chemistry model, can thus inform only a surface-level discussion of the possible effects of changing BVOCs. However, we wish to provide context for the benefits and detriments associated with changing BVOC emissions, as well as some limitations related to our model setup.

The globally decreased BVOC emissions in all scenarios could contribute a cooling effect in the future, due to expected lower tropospheric ozone concentrations, shorter methane lifetime, and enhanced photosynthesis thanks to more diffuse radiation. This could be counteracted somewhat by warming arising from the reduced formation of secondary aerosols, and it is important to note that the effects on climate are likely to vary from region to region (Rosenkranz et al., 2014). Southeast Asia and the southeastern US are populous areas that could see public health benefits from the deforestation-induced reduction of isoprene emissions and associated ozone levels. However, a sizable portion of that agricultural expansion is for growing bioenergy crops simulated in LPJ-GUESS as Miscanthus; BVOC levels would be reduced much less (or perhaps even increased) if woody bioenergy crops were grown instead on the same area (Rosenkranz et al., 2014), but that possibility is not yet included in LandSyMM. Moreover, the loss of natural land is itself associated with myriad negative health impacts (Myers et al., 2013) which are not simulated in LandSyMM, so it would be shortsighted to view deforestation-induced BVOC reductions as a public health boon. Testing whether and to what extent any of the mechanisms described in this paragraph would make a difference to regional climate and human health would require significant extension of LandSyMM, including the incorporation of new submodels.

\subsubsection{Biodiversity hotspots}

The large expansion of agricultural land in SSP3-60 has direct consequences for habitats in biodiversity hotspots, which lose over $13 \%$ of their non-agricultural land in that scenario (Fig. 4). No other scenario lost more than 8\%, and SSP1-45 actually showed a slight gain. However, note that the central African rainforest is not included in the CI hotspots, since that region did not meet the criterion regarding how much of its primary vegetation had been lost (Myers et al., 2000; Mittermeier et al., 2004). The amount of deforestation projected there in all scenarios - ranging from more than $50 \%$ in SSP1-45 to $77 \%$ in SSP3-60 - could result in great impacts to regional biodiversity. We thus checked how much area is lost if we include the five ecoregions classified by Olson et al. (2001) as Congolian swamp and lowland forests (CSLF), which together roughly correspond to the area of pasture expansion common to all scenarios, into a new "CI+CSLF" hotspot map. This paints a worse picture in all scenarios (Figs. 4, 7), increasing hotspot area loss by about $50 \%$ in SSP3-60, approximately doubling it in SSP460 and SSP5-85, and changing the 1\% gain of SSP1-45 to a $4 \%$ loss.

Hof et al. (2018) considered the effects of both climate and land use change under RCP2.6 and 6.0 on species distribution models of amphibians, birds, and mammals. They found that the area of land impacted by these combined threats was approximately equal between the two scenarios for birds and mammals (with more area affected for amphibians under RCP6.0), because although climate change was less detrimental under RCP2.6, to meet such an ambitious climate change target, that scenario required more land devoted to growing bioenergy crops. We see a similar effect: if ignoring the Miscanthus area, loss of natural land in CI+CSLF hotspots is reduced (respectively for SSP145, SSP3-60, SSP4-60, and SSP5-85) by about $100 \%, 45 \%$, $39 \%$, and $17 \%$. However, because land cleared for biofuel means less land available for other crops, a full accounting of the contribution of biofuel expansion to land conversion and thus biodiversity would require PLUM runs with no biofuel demand.

It should be noted that area loss in biodiversity hotspots will not necessarily correspond to linear decreases in species richness. Jantz et al. (2015) considered the losses of primary non-agricultural land in the LUH1 land use trajectories (Hurtt et al., 2011), which between 2005 and 2100 were $25 \%$ in RCP4.5, $40 \%$ in RCP6.0, and 58\% in RCP8.5. (Note that Jantz et al. considered only primary land as habitat: i.e., any land that had once been agriculture or experienced wood harvest was "uninhabitable".) However, they translated those values into $0.2 \%-25 \%$ of hotspot-endemic species driven to extinction by habitat loss. This is smaller than the fraction of land area because Jantz et al. (2015) used species-area curves, which model the rate of extinctions per hectare lost as high at the beginning of land clearance in a region but falling 


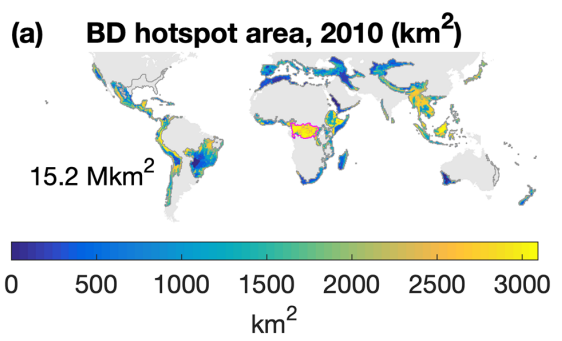

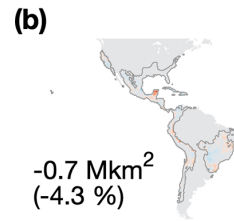

(d)

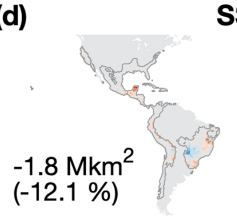

SSP1-45

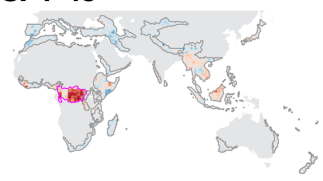

SSP4-60

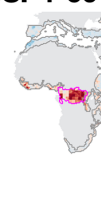

(c)

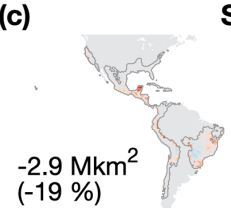

SSP3-60

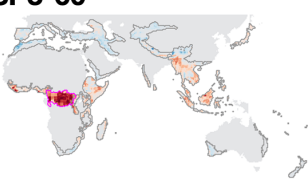

(e)

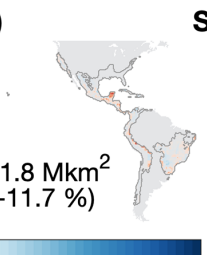

SSP5-85

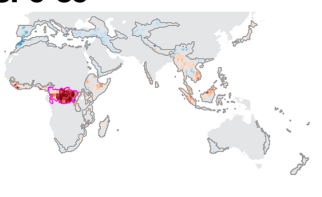

$\begin{array}{lllll}-2000 & -1000 & 0 & 1000 & 2000\end{array}$

Figure 7. (a) Area (from LUH2) of non-agricultural land in "CI+CSLF" hotspots in 2010; (b-e) change in non-agricultural land area there by 2100 for each scenario. Black outlines indicate CI hotspots; magenta outline indicates CSLF region.

as more area is cleared. This nonlinear effect is important to consider, especially considering how much land has (by definition) been cleared already in the hotspots, but such an analysis is beyond the scope of the present study. Thus, our numbers for fraction of habitat lost (or gained) should not be considered to translate directly into extinction estimates.

\section{Conclusions}

This work is among the first to comprehensively consider the impacts of future land use and land management change on a suite of ecosystem services under different possible futures of climate and socioeconomic change. Using a uniquely spatially detailed, process-based coupled model system, we show that scenarios with high socioeconomic challenges to climate change mitigation - SSP3 and SSP5 - consistently have some of the most severe consequences for the natural world and the benefits it provides humanity via carbon sequestration, biodiversity, and water regulation. These two scenarios also most strongly affect biogeochemical cycling of nitrogen and BVOCs; while increases in nitrogen losses are generally detrimental, the impact of decreased BVOC emissions is likely to vary regionally. However, various elements of uncertainty - related to PLUM parameter values, global climate model selection, and model design - affect these results and remain to be explored.
Policymakers and other stakeholders need options for how we can meet the needs of a growing and changing society while achieving climate and sustainable development goals (Benton et al., 2018). Some progress has already been made in this regard at landscape and global scales (Eitelberg et al., 2016; Verhagen et al., 2018). LandSyMM, and analyses it enables such as the ones presented here, can be another powerful tool in this aspect of the science-policy interface.

Code availability. The code for harmonizing land use and management is available for download on Zenodo (Rabin, 2019).

Supplement. The supplement related to this article is available online at: https://doi.org/10.5194/esd-11-357-2020-supplement.

Author contributions. All authors contributed to the conceptual design of LandSyMM. PAl contributed most of the initial text for Sect. 2.2. AA contributed most of the initial text regarding BVOCs in the introduction and text in Sect. 3.2.4 regarding $\left[\mathrm{CO}_{2}\right]$ inhibition. SSR composed most of this paper, although all authors contributed to its editing. SSR performed most analyses, with RH helping to interpret PLUM results. PAl and RH managed PLUM code and performed PLUM runs. SSR made changes as described to LPJGUESS code and performed LPJ-GUESS runs. 
Competing interests. The authors declare that they have no conflict of interest.

Acknowledgements. The authors would like to thank Jonathan Doelman for sharing data about the IMAGE scenarios (Doelman et al., 2018). This is paper number 44 of the Birmingham Institute of Forest Research.

Financial support. This research has been supported by the Helmholtz Association Impulse and Networking fund, the HGF ATMO program, and the UK's Global Food Security Programme project "Resilience of the UK food system to Global Shocks" (RUGS, BB/N020707/1).

The article processing charges for this open-access

publication were covered by a Research

Centre of the Helmholtz Association.

Review statement. This paper was edited by Stefan Dekker and reviewed by two anonymous referees.

\section{References}

Ahlström, A., Schurgers, G., Arneth, A., and Smith, B.: Robustness and uncertainty in terrestrial ecosystem carbon response to CMIP5 climate change projections, Environ. Res. Lett., 7, 044008-10, https://doi.org/10.1088/1748-9326/7/4/044008, 2012.

Alexander, P., Rabin, S. S., Anthoni, P., Henry, R., Pugh, T. A. M., Rounsevell, M. D. A., and Arneth, A.: Adaptation of global land use and management intensity to changes in climate and atmospheric carbon dioxide, Glob. Change Biol., 24, 2791-2809, 2018.

Arneth, A., Miller, P. A., Scholze, M., Hickler, T., Schurgers, G., Smith, B., and Prentice, I. C.: $\mathrm{CO}_{2}$ inhibition of global terrestrial isoprene emissions: Potential implications for atmospheric chemistry, Geophys. Res. Lett., 34, 73-75, 2007a.

Arneth, A., Niinemets, Ü., Pressley, S., Bäck, J., Hari, P., Karl, T., Noe, S., Prentice, I. C., Serça, D., Hickler, T., Wolf, A., and Smith, B.: Process-based estimates of terrestrial ecosystem isoprene emissions: incorporating the effects of a direct $\mathrm{CO}_{2}$-isoprene interaction, Atmos. Chem. Phys., 7, 31-53, https://doi.org/10.5194/acp-7-31-2007, 2007b.

Arneth, A., Monson, R. K., Schurgers, G., Niinemets, Ü, and Palmer, P. I.: Why are estimates of global terrestrial isoprene emissions so similar (and why is this not so for monoterpenes)?, Atmos. Chem. Phys., 8, 4605-4620, https://doi.org/10.5194/acp8-4605-2008, 2008.

Arthur, W. B.: Complexity, the Santa Fe approach, and nonequilibrium economics, Econ. J., 18, 149-166, 2010.

Asadieh, B. and Krakauer, N. Y.: Global change in streamflow extremes under climate change over the 21st century, Hydrol. Earth Syst. Sci., 21, 5863-5874, https://doi.org/10.5194/hess-21-58632017, 2017.
Ashmore, M. R.: Assessing the future global impacts of ozone on vegetation, Plant Cell Environ., 28, 949-964, 2005.

Bayer, A. D., Lindeskog, M., Pugh, T. A. M., Anthoni, P. M., Fuchs, R., and Arneth, A.: Uncertainties in the land-use flux resulting from land-use change reconstructions and gross land transitions, Earth Syst. Dynam., 8, 91-111, https://doi.org/10.5194/esd-8-91-2017, 2017.

Benton, T. G., Bailey, R., Froggatt, A., King, R., Lee, B., and Wellesley, L.: Designing sustainable landuse in a $1.5^{\circ} \mathrm{C}$ world: the complexities of projecting multiple ecosystem services from land, Curr. Opin. Env. Sust., 31, 88-95, 2018.

Brovkin, V., Boysen, L., Arora, V. K., Boisier, J. P., Cadule, P., Chini, L., Claussen, M., Friedlingstein, P., Gayler, V., van den Hurk, B. J. J. M., Hurtt, G. C., Jones, C. D., Kato, E., de NobletDucoudré, N., Pacifico, F., Pongratz, J., and Weiss, M.: Effect of anthropogenic land-use and land-cover changes on climate and land carbon storage in CMIP5 projections for the twenty-first century, J. Climate, 26, 6859-6881, 2013.

Ciais, P., Sabine, C., Bala, G., Bopp, L., Brovkin, V., Canadell, J., Chhabra, A., DeFries, R., Galloway, J., Heimann, M., Jones, C., Le Quéré, C., Myneni, R., Piao, S., and Thornton, P.: 6: Carbon and Other Biogeochemical Cycles, in: Climate Change 2013: The Physical Science Basis. Contribution of Working Group I to the Fifth Assessment Report of the Intergovernmental Panel on Climate Change, edited by: Stocker, T. F., Qin, D., Plattner, G.K., Tignor, M., Allen, S. K., Boschung, J., Nauels, A., Xia, Y., Bex, V., and Midgley, P. M., Cambridge University Press, Cambridge, UK and New York, NY, USA, 2013.

Dankers, R., Arnell, N. W., Clark, D. B., Falloon, P. D., Fekete, B. M., Gosling, S. N., Heinke, J., Kim, H., Masaki, Y., Satoh, Y., Stacke, T., Wada, Y., and Wisser, D.: First look at changes in flood hazard in the Inter-Sectoral Impact Model Intercomparison Project ensemble, P. Natl. Acad. Sci. USA, 111, 3257-3261, 2014.

Davie, J. C. S., Falloon, P. D., Kahana, R., Dankers, R., Betts, R., Portmann, F. T., Wisser, D., Clark, D. B., Ito, A., Masaki, Y., Nishina, K., Fekete, B., Tessler, Z., Wada, Y., Liu, X., Tang, Q., Hagemann, S., Stacke, T., Pavlick, R., Schaphoff, S., Gosling, S. N., Franssen, W., and Arnell, N.: Comparing projections of future changes in runoff from hydrological and biome models in ISI-MIP, Earth Syst. Dynam., 4, 359-374, https://doi.org/10.5194/esd-4-359-2013, 2013.

Di Marco, M., Harwood, T. D., Hoskins, A. J., Ware, C., Hill, S. L. L., and Ferrier, S.: Projecting impacts of global climate and land-use scenarios on plant biodiversity using compositional-turnover modelling, Glob. Change Biol., 1, 173$16,2019$.

Doelman, J. C., Stehfest, E., Tabeau, A., van Meijl, H., Lassaletta, L., Gernaat, D. E. H. J., Hermans, K., Harmsen, M., Daioglou, V., Biemans, H., van der Sluis, S., and van Vuuren, D. P.: Exploring SSP land-use dynamics using the IMAGE model: Regional and gridded scenarios of land-use change and land-based climate change mitigation, Global Environ. Chang., 48, 119-135, 2018.

Dufresne, J. L., Foujols, M. A., Denvil, S., Caubel, A., Marti, O., Aumont, O., Balkanski, Y., Bekki, S., Bellenger, H., Benshila, R., Bony, S., Bopp, L., Braconnot, P., Brockmann, P., Cadule, P., Cheruy, F., Codron, F., Cozic, A., Cugnet, D., de Noblet, N., Duvel, J. P., Ethé, C., Fairhead, L., Fichefet, T., Flavoni, S., 
Friedlingstein, P., Grandpeix, J. Y., Guez, L., Guilyardi, E., Hauglustaine, D., Hourdin, F., Idelkadi, A., Ghattas, J., Joussaume, S., Kageyama, M., Krinner, G., Labetoulle, S., Lahellec, A., Lefebvre, M. P., Lefevre, F., Levy, C., Li, Z. X., Lloyd, J., Lott, F., Madec, G., Mancip, M., Marchand, M., Masson, S., Meurdesoif, Y., Mignot, J., Musat, I., Parouty, S., Polcher, J., Rio, C., Schulz, M., Swingedouw, D., Szopa, S., Talandier, C., Terray, P., Viovy, N., and Vuichard, N.: Climate change projections using the IPSL-CM5 Earth System Model: from CMIP3 to CMIP5, Clim. Dynam., 40, 2123-2165, 2013.

Ebi, K. L. and McGregor, G.: Climate Change, Tropospheric Ozone and Particulate Matter, and Health Impacts, Environ. Health Persp., 116, 1449-1455, 2008.

Eitelberg, D. A., van Vliet, J., Doelman, J. C., Stehfest, E., and Verburg, P. H.: Demand for biodiversity protection and carbon storage as drivers of global land change scenarios, Global Environ. Chang., 40, 101-111, 2016.

Elliott, J., Deryng, D., Müller, C., Frieler, K., Konzmann, M., Gerten, D., Glotter, M., Flörke, M., Wada, Y., Best, N., Eisner, S., Fekete, B. M., Folberth, C., Foster, I., Gosling, S. N., Haddeland, I., Khabarov, N., Ludwig, F., Masaki, Y., Olin, S., Rosenzweig, C., Ruane, A. C., Satoh, Y., Schmid, E., Stacke, T., Tang, Q., and Wisser, D.: Constraints and potentials of future irrigation water availability on agricultural production under climate change., P. Natl. Acad. Sci. USA, 111, 3239-3244, 2014.

Engström, K., Olin, S., Rounsevell, M. D. A., Brogaard, S., van Vuuren, D. P., Alexander, P., Murray-Rust, D., and Arneth, A.: Assessing uncertainties in global cropland futures using a conditional probabilistic modelling framework, Earth Syst. Dynam., 7, 893-915, https://doi.org/10.5194/esd-7-893-2016, 2016 a.

Engström, K., Rounsevell, M. D. A., Murray-Rust, D., Hardacre, C., Alexander, P., Cui, X., Palmer, P. I., and Arneth, A.: Applying Occam's razor to global agricultural land use change, Environ. Modell. Softw., 75, 212-229, 2016 b.

FAOSTAT: Commodity Balances/Crops Primary Equivalent (201809-24), Food and Agriculture Organization of the United Nations, Rome, Italy, 2018a.

FAOSTAT: Commodity Balances/Livestock and Fish Primary Equivalent (2018-09-24), Food and Agriculture Organization of the United Nations, Rome, Italy, 2018b.

FAOSTAT: Food Supply (2018-09-24), Food and Agriculture Organization of the United Nations, Rome, Italy, 2018c.

Feng, Z. and Kobayashi, K.: Assessing the impacts of current and future concentrations of surface ozone on crop yield with metaanalysis, Atmos. Environ., 43, 1510-1519, 2009.

Fowler, D., Pilegaard, K., Sutton, M. A., Ambus, P., Raivonen, M., Duyzer, J., Simpson, D., Fagerli, H., Fuzzi, S., Schjoerring, J. K., Granier, C., Neftel, A., Isaksen, I. S. A., Laj, P., Maione, M., Monks, P. S., Burkhardt, J., Daemmgen, U., Neirynck, J., Personne, E., Wichink-Kruit, R., ButterbachBahl, K., Flechard, C., Tuovinen, J. P., Coyle, M., Gerosa, G., Loubet, B., Altimir, N., Gruenhage, L., Ammann, C., Cieslik, S., Paoletti, E., Mikkelsen, T. N., Ro-Poulsen, H., Cellier, P., Cape, J. N., HorvAth, L., Loreto, F., Niinemets, U., Palmer, P. I., Rinne, J., Misztal, P., Nemitz, E., Nilsson, D., Pryor, S., Gallagher, M. W., Vesala, T., Skiba, U., BrUggemann, N., Zechmeister-Boltenstern, S., Williams, J., Dowd, C. O., Facchini, M. C., de Leeuw, G., Flossman, A., Chaumerliac, N., and Erisman, J. W.: Atmospheric composition change: Ecosystems-
Atmosphere interactions, Atmos. Environ., 43, 5193-5267, 2009.

Gerten, D., Schaphoff, S., Haberlandt, U., Lucht, W., and Sitch, S.: Terrestrial vegetation and water balance - hydrological evaluation of a dynamic global vegetation model, J. Hydrol., 286, 249$270,2004$.

Haddeland, I., Heinke, J., Biemans, H., Eisner, S., Flörke, M., Hanasaki, N., Konzmann, M., Ludwig, F., Masaki, Y., Schewe, J., Stacke, T., Tessler, Z. D., Wada, Y., and Wisser, D.: Global water resources affected by human interventions and climate change, P. Natl. Acad. Sci. USA, 111, 3251-3256, 2014.

Hantson, S., Knorr, W., Schurgers, G., Pugh, T. A. M., and Arneth, A.: Global isoprene and monoterpene emissions under changing climate, vegetation, $\mathrm{CO}_{2}$ and land use, Atmos. Environ., 155, 35-45, 2017.

Haxeltine, A. and Prentice, I. C.: BIOME3: An equilibrium terrestrial biosphere model based on ecophysiological constraints, resource availability, and competition among plant functional types, Global Biogeochem. Cy., 10, 693-709, 1996.

Hirabayashi, Y., Mahendran, R., Koirala, S., Konoshima, L., Yamazaki, D., Watanabe, S., Kim, H., and Kanae, S.: Global flood risk under climate change, Nat. Clim. Change, 3, 816-821, 2013.

Hof, C., Voskamp, A., Biber, M. F., Böhning-Gaese, K., Engelhardt, E. K., Niamir, A., Willis, S. G., and Hickler, T.: Bioenergy cropland expansion may offset positive effects of climate change mitigation for global vertebrate diversity, P. Natl. Acad. Sci. USA, 10, 201807745-6, 2018.

Humpenöder, F., Popp, A., Dietrich, J. P., Klein, D., LotzeCampen, H., Bonsch, M., Bodirsky, B. L., Weindl, I., Stevanovic, M., and Müller, C.: Investigating afforestation and bioenergy CCS as climate change mitigation strategies, Environ. Res. Lett., 9, 064029, https://doi.org/10.1088/17489326/9/6/064029, 2014.

Hurtt, G. C., Chini, L. P., Frolking, S., Betts, R. A., Feddema, J., Fischer, G., Fisk, J. P., Hibbard, K., Houghton, R. A., Janetos, A., Jones, C. D., Kindermann, G., Kinoshita, T., Klein Goldewijk, K., Riahi, K., Shevliakova, E., Smith, S., Stehfest, E., Thomson, A., Thornton, P., van Vuuren, D. P., and Wang, Y. P.: Harmonization of land-use scenarios for the period 1500-2100: 600 years of global gridded annual land-use transitions, wood harvest, and resulting secondary lands, Climatic Change, 109, 117-161, 2011.

Hurtt, G. C., Chini, L., Sahajpal, R., Frolking, S., Bodirsky, B. L., Calvin, K., Doelman, J. C., Fisk, J., Fujimori, S., Goldewijk, K. K., Hasegawa, T., Havlik, P., Heinimann, A., Humpenöder, F., Jungclaus, J., Kaplan, J., Kennedy, J., Kristzin, T., Lawrence, D., Lawrence, P., Ma, L., Mertz, O., Pongratz, J., Popp, A., Poulter, B., Riahi, K., Shevliakova, E., Stehfest, E., Thornton, P., Tubiello, F. N., van Vuuren, D. P., and Zhang, X.: Harmonization of Global Land-Use Change and Management for the Period 850-2100 (LUH2) for CMIP6, Geosci. Model Dev. Discuss., https://doi.org/10.5194/gmd-2019-360, in review, 2020.

IIASA: SSP Database (version 0.93), International Institute for Applied Systems Analysis, Laxenburg, Austria, 2014.

IPBES: Summary for Policymakers of the Regional Assessment Report on Biodiversity and Ecosystem Services for Europe and Central Asia, Tech. rep., Bonn, Germany, 2018a.

IPBES: Summary for policymakers of the regional assessment report on biodiversity and ecosystem services for the Americas of 
the Intergovernmental Science-Policy Platform on Biodiversity and Ecosystem Services, Tech. rep., Bonn, Germany, 2018b.

Ito, A., Nishina, K., Reyer, C. P. O., François, L., Henrot, A.J., Munhoven, G., Jacquemin, I., Tian, H., Yang, J., Pan, S., Morfopoulos, C., Betts, R. A., Hickler, T., Steinkamp, J., Ostberg, S., Schaphoff, S., Ciais, P., Chang, J., Rafique, R., Zeng, N., and Zhao, F.: Photosynthetic productivity and its efficiencies in ISIMIP2a biome models: benchmarking for impact assessment studies, Environ. Res. Lett., 12, 085001-14, 2017.

Jantz, S. M., Barker, B., Brooks, T. M., Chini, L. P., Huang, Q., Moore, R. M., Noel, J., and Hurtt, G. C.: Future habitat loss and extinctions driven by land-use change in biodiversity hotspots under four scenarios of climate-change mitigation, Conserv. Biol., 29, 1122-1131, 2015.

Kaldor, N.: The irrelevance of equilibrium economics, Econ. J., 82, 1237-1255, 1972.

KC, S. and Lutz, W.: The human core of the shared socioeconomic pathways: Population scenarios by age, sex and level of education for all countries to 2100, Global Environ. Chang., 42, 181192, 2017.

Kesselmeier, J. and Staudt, M.: Biogenic Volatile Organic Compounds (VOC): An Overview on Emission, Physiology and Ecology, J. Atmos. Chem., 33, 23-88, 1999.

Keyzer, M. A., Merbis, M. D., Pavel, I. F. P. W., and van Wesenbeeck, C. F. A.: Diet shifts towards meat and the effects on cereal use: can we feed the animals in 2030?, Ecol. Econ., 55, 187-202, 2005.

Koirala, S., Hirabayashi, Y., Mahendran, R., and Kanae, S.: Global assessment of agreement among streamflow projections using CMIP5 model outputs, Environ. Res. Lett., 9, 064017-12, 2014.

Krause, A., Pugh, T. A. M., Bayer, A. D., Doelman, J. C., Humpenöder, F., Anthoni, P., Olin, S., Bodirsky, B. L., Popp, A., Stehfest, E., and Arneth, A.: Global consequences of afforestation and bioenergy cultivation on ecosystem service indicators, Biogeosciences, 14, 4829-4850, https://doi.org/10.5194/bg-144829-2017, 2017.

Lawrence, D. M., Slater, A. G., and Swenson, S. C.: Simulation of Present-Day and Future Permafrost and Seasonally Frozen Ground Conditions in CCSM4, J. Climate, 25, 2207-2225, 2012.

Lawrence, P. J., Lawrence, D. M., and Hurtt, G. C.: Attributing the Carbon Cycle Impacts of CMIP5 Historical and Future Land Use and Land Cover Change in the Community Earth System Model (CESM1), J. Geophys. Res.-Biogeo., 123, 1732-1755, 2018.

Lindeskog, M., Arneth, A., Bondeau, A., Waha, K., Seaquist, J., Olin, S., and Smith, B.: Implications of accounting for land use in simulations of ecosystem carbon cycling in Africa, Earth Syst. Dynam., 4, 385-407, https://doi.org/10.5194/esd-4-3852013, 2013.

Mitra-Kahn, B. H.: Debunking the Myths of Computable General Equilibrium Models, Tech. rep., Schwartz Center for Economic Policy Analysis, and Department of Economics, The New School for Social Research,New York City, New York, USA, 2008.

Mittermeier, R. A., Gil, P. R., Hoffmann, M., Pilgrim, J., Brooks, T. M., Mittermeier, C. G., Lamoreux, J., and da Fonseca, G. A. B.: Hotspots Revisited: Earth's Biologically Richest and Most Endangered Terrestrial Ecoregions: Conservation International, Conservation International, Arlington, Virginia, USA, 2004.
Molotoks, A., Stehfest, E., Doelman, J., Albanito, F., Fitton, N., Dawson, T. P., and Smith, P.: Global projections of future cropland expansion to 2050 and direct impacts on biodiversity and carbon storage, Glob. Change Biol., 24, 5895-5908, 2018.

Myers, N., Mittermeier, R. A., Mittermeier, C. G., da Fonseca, G. A. B., and Kent, J.: Biodiversity hotspots for conservation priorities, Nature, 403, 853-858, 2000.

Myers, S. S., Gaffikin, L., Golden, C. D., Ostfeld, R. S., Redford, K. H., Ricketts, T. H., Turner, W. R., and Osofsky, S. A.: Human health impacts of ecosystem alteration., P. Natl. Acad. Sci. USA, 110, 18753-18760, 2013.

Myhre, G., Shindell, D. T., Bréon, F.-M., Collins, W., Fuglestvedt, J., Huang, J., Koch, D., Lamarque, J.-F., Lee, D., Mendoza, B., Nakajima, T., Robock, A., Stephens, G., and Zhang, H.: 8: Anthropogenic and natural radiative forcing, 659-740, Cambridge, UK and New York, NY, USA, 2013.

Newbold, T., Hudson, L. N., Hill, S. L. L., Contu, S., Lysenko, I., Senior, R. A., Börger, L., Bennett, D. J., Choimes, A., Collen, B., Day, J., De Palma, A., Díaz, S., Echeverria-Londoño, S., Edgar, M. J., Feldman, A., Garon, M., Harrison, M. L. K., Alhusseini, T., Ingram, D. J., Itescu, Y., Kattge, J., Kemp, V., Kirkpatrick, L., Kleyer, M., Correia, D. L. P., Martin, C. D., Meiri, S., Novosolov, M., Pan, Y., Phillips, H. R. P., Purves, D. W., Robinson, A., Simpson, J., Tuck, S. L., Weiher, E., White, H. J., Ewers, R. M., Mace, G. M., Scharlemann, J. P. W., and Purvis, A.: Global effects of land use on local terrestrial biodiversity, Nature, 520, 45-50, 2015.

Olin, S., Lindeskog, M., Pugh, T. A. M., Schurgers, G., Wårlind, D., Mishurov, M., Zaehle, S., Stocker, B. D., Smith, B., and Arneth, A.: Soil carbon management in large-scale Earth system modelling: implications for crop yields and nitrogen leaching, Earth Syst. Dynam., 6, 745-768, https://doi.org/10.5194/esd-6745-2015, 2015a.

Olin, S., Schurgers, G., Lindeskog, M., Wårlind, D., Smith, B., Bodin, P., Holmér, J., and Arneth, A.: Modelling the response of yields and tissue $\mathrm{C}: \mathrm{N}$ to changes in atmospheric $\mathrm{CO}_{2}$ and $\mathrm{N}$ management in the main wheat regions of western Europe, Biogeosciences, 12, 2489-2515, https://doi.org/10.5194/bg-122489-2015, 2015b.

Olson, D. M., Dinerstein, E., Wikramanayake, E. D., Burgess, N. D., Powell, G. V. N., Underwood, E. C., DAmico, J. A., Itoua, I., Strand, H. E., Morrison, J. C., Loucks, C. J., Allnutt, T. F., Ricketts, T. H., Kura, Y., Lamoreux, J. F., Wettengel, W. W., Hedao, P., and Kassem, K. R.: Terrestrial Ecoregions of the World: A New Map of Life on Earth, BioScience, 51, 933-938, 2001.

O’Neill, B. C., Kriegler, E., Riahi, K., Ebi, K. L., Hallegatte, S., Carter, T. R., Mathur, R., and van Vuuren, D. P.: A new scenario framework for climate change research: the concept of shared socioeconomic pathways, Climatic Change, 122, 387-400, 2014.

O’Neill, B. C., Kriegler, E., Ebi, K. L., Kemp-Benedict, E., Riahi, K., Rothman, D. S., van Ruijven, B. J., van Vuuren, D. P., Birkmann, J., Kok, K., Levy, M., and Solecki, W.: The roads ahead: Narratives for shared socioeconomic pathways describing world futures in the 21st century, Global Environ. Chang., 42, 169-180, https://doi.org/10.1016/j.gloenvcha.2015.01.004, 2017.

Pastick, N. J., Jorgenson, M. T., Wylie, B. K., Nield, S. J., Johnson, K. D., and Finley, A. O.: Distribution of near-surface per- 
mafrost in Alaska: Estimates of present and future conditions, Remote Sens. Environ., 168, 301-315, 2015.

Popp, A., Calvin, K., Fujimori, S., Havlik, P., Humpenöder, F., Stehfest, E., Bodirsky, B. L., Dietrich, J. P., Doelmann, J. C., Gusti, M., Hasegawa, T., Kyle, P., Obersteiner, M., Tabeau, A., Takahashi, K., Valin, H., Waldhoff, S., Weindl, I., Wise, M., Kriegler, E., Lotze-Campen, H., Fricko, O., Riahi, K., and van Vuuren, D. P.: Land-use futures in the shared socio-economic pathways, Global Environ. Chang., 42, 331-345, 2017.

Portmann, F. T., Siebert, S., and Döll, P.: MIRCA2000 - Global monthly irrigated and rainfed crop areas around the year 2000: A new high-resolution data set for agricultural and hydrological modeling, Global Biogeochem. Cy., 24, GB1011, https://doi.org/10.1029/2008GB003435, 2010.

Pugh, T.: A roadmap for improving the modelling of physiological and yield responses to the rising of atmospheric $\mathrm{CO}_{2}$, in preparation, 2020.

Quesada, B., Arneth, A., and de Noblet-Ducoudré, N.: Atmospheric, radiative, and hydrologic effects of future land use and land cover changes: A global and multimodel climate picture, J. Geophys. Res.-Atmos., 122, 5113-5131, 2017.

Rabin, S. S.: Harmonizing LandSyMM with historical data, Zenodo, https://doi.org/10.5281/zenodo.3336114, 2019.

Rap, A., Scott, C. E., Reddington, C. L., Mercado, L., Ellis, R. J., Garraway, S., Evans, M. J., Beerling, D. J., MacKenzie, A. R., Hewitt, C. N., and Spracklen, D. V.: Enhanced global primary production by biogenic aerosol via diffuse radiation fertilization, Nat. Geosci., 11, 640-644, https://doi.org/10.1038/s41561-0180208-3, 2018.

Rasulov, B., Talts, E., and Niinemets, Ü.: Spectacular Oscillations in Plant Isoprene Emission under Transient Conditions Explain the Enigmatic $\mathrm{CO}_{2}$ Response, Plant Physiol., 172, 2275-2285, 2016.

Rockström, J., Steffen, W., Noone, K., Persson, Å., Chapin III, F. S., Lambin, E. F., Lenton, T. M., Scheffer, M., Folke, C., Schnellnhuber, H. J., Nykvist, B., de Wit, C. A., Hughes, T., van der Leeuw, S., Rodhe, H., Sörlin, S., Snyder, P. K., Costanza, R., Svedin, U., Falkenmark, M., Karlberg, L., Corell, R. W., Fabry, V. J., Hansen, J., Walker, B., Liverman, D., Richardson, K., Crutzen, P., and Foley, J. A.: A safe operating space for humanity, Nature, 461, 472-475, https://doi.org/10.1038/461472a, 2009.

Rogelj, J., Shindell, D. T., Jiang, K., Fifita, S., Forster, P., Ginzburg, V., Handa, C., Kheshagi, H., Kobayashi, S., Kriegler, E., Mundaca, L., Séférian, R., and Vilariño, M. V.: 2: Mitigation pathways compatible with $1.5^{\circ} \mathrm{C}$ in the context of sustainable development, in: Global warming of $1.5^{\circ} \mathrm{C}$ : An IPCC Special Report on the impacts of global warming of $1.5^{\circ} \mathrm{C}$ above pre-industrial levels and related global greenhouse gas emission pathways, in the context of strengthening the global response to the threat of climate change, sustainable development, and efforts to eradicate poverty, edited by: Masson-Delmotte, V., Zhai, P., Pörtner, H. O., Roberts, D., Skea, J., Shukla, P. R., Pirani, A., Moufouma-Okia, W., Péan, C., Pidcock, R., Connors, S., Matthews, J. B. R., Chen, Y., Zhou, X., Gomis, M. I., Lonnoy, E., Maycock, T., Tignor, M., and Waterfield, T., 93-174, Cambridge University Press, Cambridge, UK and New York, NY, USA, 2018.
Rosenkranz, M., Pugh, T. A. M., Schnitzler, J.-P., and Arneth, A.: Effect of land-use change and management on biogenic volatile organic compound emissions - selecting climate-smart cultivars, Plant Cell Environ., 38, 1896-1912, 2014.

Schurgers, G., Arneth, A., Holzinger, R., and Goldstein, A. H.: Process-based modelling of biogenic monoterpene emissions combining production and release from storage, Atmos. Chem. Phys., 9, 3409-3423, https://doi.org/10.5194/acp-9-3409-2009, 2009.

Shcherbak, I., Millar, N., and Robertson, G. P.: Global metaanalysis of the nonlinear response of soil nitrous oxide $\left(\mathrm{N}_{2} \mathrm{O}\right)$ emissions to fertilizer nitrogen, P. Natl. Acad. Sci. USA, 111, 9199-9204, 2014.

Simpson, R. D., Sedjo, R. A., and Reid, J. W.: Valuing Biodiversity for Use in Pharmaceutical Research, J. Polit. Econ., 104, 163185, 1996.

Sindelarova, K., Granier, C., Bouarar, I., Guenther, A., Tilmes, S., Stavrakou, T., Müller, J.-F., Kuhn, U., Stefani, P., and Knorr, W.: Global data set of biogenic VOC emissions calculated by the MEGAN model over the last 30 years, Atmos. Chem. Phys., 14, 9317-9341, https://doi.org/10.5194/acp-14-9317-2014, 2014.

Smith, B., Prentice, I. C., and Sykes, M. T.: Representation of vegetation dynamics in the modelling of terrestrial ecosystems: comparing two contrasting approaches within European climate space, Global Ecol. Biogeogr., 10, 621-637, 2001.

Smith, B., Wårlind, D., Arneth, A., Hickler, T., Leadley, P., Siltberg, J., and Zaehle, S.: Implications of incorporating $\mathrm{N}$ cycling and $\mathrm{N}$ limitations on primary production in an individualbased dynamic vegetation model, Biogeosciences, 11, 20272054, https://doi.org/10.5194/bg-11-2027-2014, 2014.

Sporre, M. K., Blichner, S. M., Karset, I. H. H., Makkonen, R., and Berntsen, T. K.: BVOC-aerosol-climate feedbacks investigated using NorESM, Atmos. Chem. Phys., 19, 4763-4782, https://doi.org/10.5194/acp-19-4763-2019, 2019.

Szogs, S., Arneth, A., Anthoni, P., Doelman, J. C., Humpenöder, F., Popp, A., Pugh, T. A. M., and Stehfest, E.: Impact of LULCC on the emission of BVOCs during the 21st century, Atmos. Environ., 165, 73-87, 2017.

Tang, Q. and Lettenmaier, D. P.: 21st century runoff sensitivities of major global river basins, Geophys. Res. Lett., 39, L06403, , https://doi.org/10.1029/2011GL050834, 2012.

Taylor, K. E., Stouffer, R. J., and Meehl, G. A.: An Overview of CMIP5 and the Experiment Design, B. Am. Meteorol. Soc., 93, 485-498, 2012.

Tilman, D., Balzer, C., Hill, J., and Befort, B. L.: Global food demand and the sustainable intensification of agriculture, P. Natl. Acad. Sci. USA, 108, 20260-20264, 2011.

Tilman, D., Isbell, F., and Cowles, J. M.: Biodiversity and Ecosystem Functioning, Ann. Rev. Ecol. Evol. S., 45, 471-493, 2014.

van Vuuren, D. P., Edmonds, J., Kainuma, M., Riahi, K., Thomson, A., Hibbard, K., Hurtt, G. C., Kram, T., Krey, V., Lamarque, J.-F., Masui, T., Meinshausen, M., Nakicenovic, N., Smith, S. J., and Rose, S. K.: The representative concentration pathways: an overview, Climatic Change, 109, 5-31, 2011.

van Vuuren, D. P., Stehfest, E., Gernaat, D. E. H. J., Berg, M., Bijl, D. L., Boer, H. S., Daioglou, V., Doelman, J. C., Edelenbosch, O. Y., Harmsen, M., Hof, A. F., and Sluisveld, M. A. E.: Alternative pathways to the $1.5^{\circ} \mathrm{C}$ target reduce the need for 
negative emission technologies. Nat. Clim. Change 8, 391-397, https://doi.org/10.1038/s41558-018-0119-8, 2018.

Verhagen, W., van der Zanden, E. H., Strauch, M., van Teeffelen, A. J. A., and Verburg, P. H.: Optimizing the allocation of agri-environment measures to navigate the trade-offs between ecosystem services, biodiversity and agricultural production, Environ. Sci. Pol., 84, 186-196, 2018.

Vitousek, P. M., Aber, J. D., Howarth, R. W., Likens, G. E., Matson, P. A., Schindler, D. W., Schlesinger, W. H., and Tilman, D. G.: Human Alteration of the Global Nitrogen Cycle: Sources and Consequences, Ecol. Appl., 7, 737-750, 1997.

Weindl, I., Popp, A., Bodirsky, B. L., Rolinski, S., LotzeCampen, H., Biewald, A., Humpenöder, F., Dietrich, J. P., and Stevanovic, M.: Livestock and human use of land: Productivity trends and dietary choices as drivers of future land and carbon dynamics, Global Planet. Change, 159, 1-10, 2017.

Wheater, H. and Evans, E.: Land use, water management and future flood risk, Land Use Policy, 26, S251-S264, 2009.
Wilhite, D. A. and Glantz, M. H.: Understanding: the drought phenomenon: the role of definitions, Water Int., 10, 111-120, 1985.

Yang, W. and Omaye, S. T.: Air pollutants, oxidative stress and human health, Mutat. Res.-Genet. Tox., 674, 45-54, 2009.

Young, P. J., Arneth, A., Schurgers, G., Zeng, G., and Pyle, J. A.: The $\mathrm{CO}_{2}$ inhibition of terrestrial isoprene emission significantly affects future ozone projections, Atmos. Chem. Phys., 9, 27932803, https://doi.org/10.5194/acp-9-2793-2009, 2009.

Zhang, B., Tian, H., Lu, C., Dangal, S. R. S., Yang, J., and Pan, S.: Global manure nitrogen production and application in cropland during 1860-2014: a 5 arcmin gridded global dataset for Earth system modeling, Earth Syst. Sci. Data, 9, 667-678, https://doi.org/10.5194/essd-9-667-2017, 2017.

Zhu, Q., Jiang, H., Peng, C., Liu, J., Fang, X., Wei, X., Liu, S., and Zhou, G.: Effects of future climate change, $\mathrm{CO}_{2}$ enrichment, and vegetation structure variation on hydrological processes in China, Global Planet. Change, 80-81, 123-135, 2012. 